\title{
2 The Syntax of V2
}

The basis of the verb second phenomenon can be informally described as in (1).

(1) Description of the verbs second linearization:

In V2-clauses, the finite verb occupies the second position of the clause.

Obviously, the situation is a little more complicated. The V2-phenomenon can be divided into three core issues: The position of the finite verb, specifying the preverbal element(s) and explaining its root character. The first two issues will be addressed in this chapter. The third one can only be touched because it is a complex topic on its own and not central to the issues in the following chapters of this monograph.

The first section will discuss the core phenomenon and also some cases in which the V2-requirement conflicts with other areas of the grammar. Section 2.2 shows that, due to discourse-pragmatic reasons, sentences may actually show reduced or extended V2-structures. The data in the first two sections is presented with as little theoretical assumptions as possible because these are the empirical observations that must be covered by all syntactic theories. Only in Section 2.3 will I discuss analyses of the generative grammar tradition and highlight the explanatory benefit of the respective accounts.

\subsection{Observations: The facts about V2}

In this section, I present the basic observations regarding word order regularities in German, representative for V2-languages in general. This is followed by more elaborate discussion of cases in which finite verbs cannot move into the V2-position (Section 2.1.3) and elements that cannot precede the finite verb in V2clauses (Section 2.1.4). The discussion will show that the regularities of V2 are never suspended but may conflict with other grammatical restrictions.

\subsubsection{The core cases: V2, V1 and V-final}

V2-order can be best illustrated with declarative and $w h$-interrogative clauses, as in (2) and (3). Either one of the clausal constituents may precede the finite verb, such as the subject in (2a), the object in (2b), or the adverb in (2c). The same holds for the corresponding $w h$-interrogatives in (3). 
(2) Declaratives

a. Der Junge hat gestern den Kuchen gegessen. the boy has yesterday the cake eaten 'The boy has eaten the cake yesterday.'

b. Den Kuchen hat der Junge gestern gegessen. the cake has the boy yesterday eaten 'The boy has eaten the cake yesterday.'

c. Gestern hat der Junge den Kuchen gegessen. yesterday has the boy the cake eaten 'Yesterday, the boy has eaten the cake.'

(3) Wh-interrogatives

a. Was hat der Junge gestern gegessen? what has the boy yesterday eaten 'What did the boy eat yesterday?'

b. Wer hat gestern den Kuchen gegessen? who has yesterday the cake eaten 'Who ate the cake yesterday?'

c. Wann hat der Junge den Kuchen gegessen? when has the boy the cake eaten 'When did the boy eat the cake?'

Two other core sentence types, polar interrogative and imperative rather show V1patterns with the finite verb in sentence-initial position, as in (4) and (5). ${ }^{1}$

(4) Polar interrogatives

a. Hat der Junge gestern den Kuchen gegessen?

has the boy yesterday the cake eaten

'Did the boy eat the cake yesterday?'

b. \# Der Junge hat gestern den Kuchen gegessen? the boy has yesterday the cake eaten

c. \# Gestern hat der Junge den Kuchen gegessen? yesterday has the boy the cake eaten

1 The sentences in (4b-4d) are syntactically well-formed strings and may even receive an interrogative interpretation. However, these are so-called declarative questions that have to be differentiated from true polar interrogatives because they require a very specific utterance context (see Gunlogson 2002, Truckenbrodt 2006a: 259). 
d. \# Den Kuchen hat der Junge gestern gegessen? the cake has the boy yesterday eaten

(5) Imperatives
a. Iss heute den Kuchen! eat today the cake 'Eat the cake today!'
b. * Den Kuchen iss heute! the cake eat today
c. * Heute iss den Kuchen! today eat the cake

In subordinate clauses, the finite verb appears only in the clause-final position and not in the corresponding V2/V1-positions, as illustrated in (6). ${ }^{2}$

(6) a. Es it gut, dass der Junge 〈 ${ }^{\star}$ hat〉 gestern den Kuchen gegessen 〈hat〉. it is good that the boy has yesterday the cake eaten has 'It is good that the boy ate the cake yesterday.'

b. Es ist klar, was 〈`hat〉 der Junge gestern gegessen 〈hat〉. It is clear what has the boy yesterday eaten has 'It is clear what the boy ate yesterday.'

c. Es ist unklar, ob 〈^hat〉 der Junge $\left\langle{ }^{\star}\right.$ hat $\rangle$ gestern den Kuchen it is unclear whether has the boy has yesterday the cake gegessen 〈hat .

eaten has

'It is unclear whether the boy ate the cake yesterday.'

This short descriptive sample suffices to conclude that the verb position in German (and other V2-languages) is clause-type specific. We observe a major difference between main and subordinate clauses: In subordinate clauses, the finite verb appears uniformly in the clause-final position. In main clauses, the verb appears always in the left periphery, either in first or second position. In German linguistics, these two verb positions are taken to be the anchor points for a descriptive model that divides the sentences into three fields (Drach 1937): The slot preceding the finite verb in V1/V2-clauses is called the prefield, the slot between the finite

\footnotetext{
2 I will exclude the discussion of embedded V2-clauses because that phenomenon is still discussed controversially and does, as far as I can see, not contribute anything relevant to the central objective of this investigation, the processing of V2. The interested reader is referred to Heycock (2006) and Freywald (2014).
} 
verb and the non-finite verbs in V1/V2-clauses is called the middle field, and the slot following the right-peripheral verbal element in main and embedded clauses is called the postfield. In the following, I will refer to these fields descriptively in order to avoid specific syntactic analysis, before discussing those in Section 2.3.

(7) prefield | V2 | middle field

Gestern hat der Junge den Kuchen

Yesterday has the boy the cake

\section{non-finite verb}

gegessen, eaten postfield

nachdem ... after ...

\subsubsection{The prefield: What precedes the finite verb?}

Above, we have already seen that the second position is not defined in terms of morphological words but in terms of syntactic constituents, which is also illustrated in (8). The object precedes the finite verb, irrespective of its length.

(8) [Den (mit Schkolade überzogenen) Kuchen] hat der Junge gestern the with chocolate covered cake has the boy yesterday gegessen.

eaten

'The boy ate the (with chocolate covered) cake yesterday.'

Consequently, also larger constituents such as VPs and subordinate clauses may occupy the prefield, as is shown in (9).

(9) a. [Gestern den Kuchen gegessen] hat der Junge (sicherlich nicht). yesterday the cake eaten has the boy surely not 'Yesterday, the boy did definitely not eat the cake.'

b. [Weil er Hunger hatte] hat der Junge gestern den Kuchen because he hunger had has the boy yesterday the cake gegessen.

eaten

'The boy ate the cake yesterday because he was hungry.'

In Section 2.1.4, I will discuss restrictions on prefield elements. Some specific forms of complex prefields are presented in Section 2.2.3.

\subsubsection{Restrictions on V2-movement}

The most robust restriction on V2-movement is a corollary of the V2-generalization: Only finite verbs move, non-finite verbs do not. This restriction appears to be 
inviolable. Even though German exhibits a range of non-finite matrix clause constructions, as discussed in Gärtner (2013), none of these show a non-finite verb in V2-position. Therefore we may conclude that being some kind of independent clause is not sufficient to trigger verb movement. A necessary requirement for V2-movement is finiteness.

Among the finite clauses, two different restrictions on V2-movement have been observed: An external restriction in which the finite verb is 'trapped' within the surface scope of a comparative operator and cannot be moved. Second, an internal restriction: Complex lexemes with more than one particle attached to the base exhibit a morphological structure that leads to a dilemmatic conflict of morphosyntactic well-formedness conditions under verb movement.

\subsubsection{External constraint: Configurational restrictions in scope taking comparative operators}

Haider (2010: 64-65) observed that verbs which are the target of an adverbial comparison operator cannot move out of the surface scope of such an operator. The verb verdreifachen 'triple' is perfectly acceptable as a finite verb in the V-final embedded clause in (10a), and as a participle in the main clause in (10b), irrespective of the presence of the comparative adverbial mehr als 'more than'. However, if the verb leaves the surface scope of the comparative operator the structure becomes ungrammatical, irrespective of whether the movement targets the V2-position, as in (10c), or the prefield as in (10d). Additionally, example (10e) shows that movement of the verb is not banned per se. If the comparative operator is topicalized together with the verb, the structure is completely acceptable. The same results are obtained for the equative operator so gut wie (verdoppelt) 'as much as (doubled)' (Haider 2010: 65).

(10) GERMAN

a. ... dass sich der Verlust (mehr als) verdreifachte (soweit ich das that itself the deficit more than tripled insofar I that beurteilen kann)

assess can

b. Dann hat sich der Verlust (mehr als) verdreifacht hat (soweit ich das then has itself the deficit more than tripled insofar I that beurteilen kann). assess can 
c. Dann verdreifachte sich derVerlust ( ${ }^{\star}$ mehr als) verdreifachte (soweit then tripled itself the deficit more than insofar ich das beurteilen kann).

I that assess can

d. Verdreifacht hat sich der Verlust (*mehr als) verdreifacht hat (soweit tripled has itself the deficit more than insofar ich das beurteilen kann)

I that assess can

e. [Mehrals verdreifacht] hat sich der Verlust mehr als verdreifacht hat more than tripled has itself the deficit

(soweit ich das beurteilen kann). insofar I that assess can

'The deficit has more than tripled, at least as far as I can tell'

A cross-lingustic comparison shows that such comparative structures are movement-phobic also in other, non-V2 languages. The English and Italian paradigms in (11) and (12), respectively, show exactly the same pattern as their German equivalents. As soon as the target of comparison is not within the scope domain of the operator in the surface form, the structure is ungrammatical. Example (11a) shows that a verb like triple is fine in the surface scope of an operator like more than. (11b) shows that a verb may be fronted, but fronting out of the operator scope in (11c) is deviant.

(11) ENGLISH

a. The value (has) [far more than merely tripled].

b. (He said that the value would triple, and) tripled $_{1}$ the value has indeed

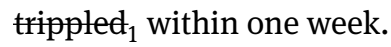

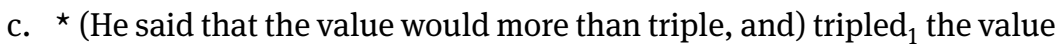
has indeed [more than tripled ${ }_{1}$ ] within one week.

(Haider 2000b: 159, Haider 2010: 64)

Example (12a) presents a similar configuration with the Italian verb triplicare "triple" in the scope of a comparative operator. Destroying the surface scope relation results in unacceptability irrespective of whether the verb is fronted as in (12b) or the operator phrase is moved as in (12c).

(12) ITALIAN

a. Il valore si è [molto più che solo triplicato]. the value REFL is much more than only tripled 
b. *Il valore si triplica ${ }_{1}$ [molto più che solo triplica ${ }_{1}$ ]. the value REFL tripled much more than only

c. *Il valore [molto più che solo] $]_{1}$ si molto più che solo $_{1}$ triplica. The value much more than only REFL tripled

(Haider 2000b: 159)

Additional support for the assumption that this ban is specific to the comparative environment can be obtained from the inspection of comparative constructions involving non-verbal elements, as illustrated for adjectives in (13), for adverbials in (14), and for $\mathrm{DPs}^{3}$ in (15).

(13) a. Dann war Christopher mehr als betrunken war. then was Christopher more than drunk 'Then Christopher was more than drunk.'

b. Betrunken ${ }_{1}$ war Christopher ( ${ }^{\star}$ mehr als) betrunken ${ }_{1}$.rar. drunk was Christopher more than

c. [Mehr als betrunken $]_{1}$ war Christopher betrunken w war. more than drunk was Christopher

(14) a. Dann wird dieser Kurs mehr als doppelt gewertet wird. then will this course more than double valued 'Then this course will count more than double.'

3 The comparison actually does not target the noun but the numeral. A variant exists that looks like a possible extraction case. However, the fronted noun must be in the plural, see (i.a). Example (i.b) shows that the plural noun cannot originate in the position following the numeral eine 'one'. Example (i.c) shows that the plural stems from a position directly following the comparator mehr 'more'. These comparative constructions seem to involve two instances of the lexeme MUTTER 'mother' of which maximally one can be spelled out, as illustrated in (i.d). Only the higher instance can be dislocated, the lower one has to remain in the operator scope even if it is not spelled out.

(i) a. Mütter/ ${ }^{*}$ Mutter hat Christopher offensichtlich mehr als eine. mothers mother has Christopher obviously more than one

b. Dann hat Christopher offensichtlich mehr als eine ${ }^{*}$ Mütter/ Mutter. Then has Christopher obviously more than one mothers mother

c. Dann hat Christopher offensichtlich mehr Mütter als eine (*Mutter). then has Christopher obviously more mothers than one mother

d. Mütter ${ }_{1}$ hat Christopher offensichtlich mehr Mütter ${ }_{1}$ als eine Mutter. mothers has Christopher obviously more that one mother 'Christopher has obviously more than one mother.' 
b. Doppelt 1 wird dieser Kurs ( ${ }^{\star}$ mehr als $)$ doppelt ${ }_{1}$ gewertet wird. double will this course more than valued

c. [Mehr als doppelt $]_{1}$ wird dieser Kurs mehr als doppelt ${ }_{1}$ gewertet more than double will this course valued wird.

(15) a. Dann hat Christopher offensichtlich mehr als eine Mutter hat. then has Christopher obviously more than one mother 'Then Christopher has obviously more than one mother.'

b. [Eine Mutter $]_{1}$ hat Christopher offensichtlich ( ${ }^{\star}$ mehr als) eine Mutter ${ }_{1}$ one mother has Christopher obviously more than hat.

c. $[\text { Mehr als eine Mutter }]_{1}$ hat Christopher offensichtlich mehr als eine Mutter $_{1}$ more than one mother has Christopher obviously hat.

Thus, there seems to be a cross-categorial and cross-linguistic restriction on extracting the target of comparison out of the surface scope of the comparative operator. This restriction is arguably so strong that it cannot be violated, not even by a generalized movement operation such as V2-movement.

The following observation sheds some more light on this ban. I assume that the comparison operator is a focus-sensitive operator. The resulting configuration is therefore an association with focus-construction (see Section 3.3.1) in which the interpretation changes according to the focus-background structure, as illustrated in (16). The operator needs a focused constituent in its scope.

(16) a. Christopher hat sich mehrals (nur) [eín $]_{\text {Foc Auto gekauft. (mindestens }}$ Christopher has REFL more than just one car bought zwei)

'Christopher bought more than just óne car. (At least two.)'

b. Christopher hat sich mehr als (nur) [ein Aúto] $]_{\text {Foc }}$ gekauft. (Dieser Christopher has REFL more that just one car bought Jaguar ist ein Stück Zeitgeschichte)

'Christopher bough more than just a cár. (This Jaguar is a piece of history.)'

The ban on movement, therefore, can be reduced to a requirement of surface focus/accent marking. To demonstrate this, let us first look at the derived/metaphorical 
use of mehr als 'more than', as in (17). In (17a) the whole particle verb anschreien 'shout at' is in the surface scope of the operator. Hence, the alternatives to the predicate may include another predicate such as schubsen 'shove', as indicated in the continuation in (17a). In (17b), the verbal part is moved to the V2-position and only the particle remains in the surface scope position of the operator. Even though the verb meaning remains intact, the focus-sensitive operator operates on different semantic alternatives, as indicated by the continuations in (17b). A felicitous continuation can only refer to a more extreme alternative of a shouting event. An event of a different type, such as shoving, is excluded. This indicates that the surface element constitutes the basis for the computation of focus alternatives by the focus-sensitive operator mehr als 'more than'.

a. Er hat ihn mehr als (nur) [án-geschrien] $]_{\mathrm{Foc}}$ (Er hat ihn mindestens he has him more than just at-shouted he has him at least geschubst)

shoved

'He has more than (just) shouted at him. (He has at least shoved him.)'

b. Er schreit ihn mehrals (nur) [án] $]_{\mathrm{FOC}}$ schreit. (Er wird ihn \#mindestens he shouts him more than just at he will him at least schubsen/ regelrecht zusammen-brüllen)

shove downright together-shout

'He is more than (just) shouting AT him. (He will \#at least shove him/ downright shout him down.)'

Two predictions follow from the hypothesis that only the surface focus exponent is constitutive for focus-sensitive operators such as mehr als 'more than' to generate the relevant alternatives: First, the surface focus exponent must not be null. Second, a meaningful focus alternative to the surface focus exponent must exist. The first prediction is obviously borne out, as illustrated by examples (10)-(15) above. The consequences of the second prediction can be illustrated with idiomatic constructions such as the particle verb anfangen 'start' (lit. 'on-catch') in (18). If the whole verb occurs in the focus of the operator, as in (18a), the relevant alternatives depict events that are well beyond the starting point. If the verb is split up by V2-movement, as in (18b), the focus alternatives are computed only with respect to the particle. However, alternative particles do not lead to felicitous alternatives to the idiomatic meaning. 
(18) a. Er hat mehr als (nur) [án-gefangen $]_{\mathrm{Foc}}$. (Er ist schon beinahe He has more than just on-catched he is already almost fertig.)

done

'He has more than just started. (He’s already almost done.)'

b. ??/^ Er fängt mehr als (nur) [án] $]_{\text {Foc fängt. (\#Er wird es auch }}$ He catched more than just on he will it also beenden)

finish

A similar observation can be made for the idiom Süßholz raspeln 'sweet-talk' (lit. 'rasp licorice') in (19). If the entire predicate complex is within the scope of the operator, as in (19a), the alternatives are generated with respect to the idiomatic meaning. In (19b), on the other hand, only the DP of the idiomatic predicate complex is within the surface scope of the operator. Hence, the focus alternatives range only over things that can be rasped, which do not constitute felicitous alternatives to the idiomatic meaning. Example (19c) shows that without the focussensitive operator mehr als, such predicates may be split by V2-movement without blocking the idiomatic meaning.

(19) a. Er hat mehr als (nur) [Süßholz geraspelt $]_{\mathrm{FOC}}$ hat. (Er hat sich He has more than just licorice rasped he has himself richtig an sie rangeschmissen.)

actually at her at-thrown

'He has more than just sweet-talked. (He actually flinged himself at her.)'

b. Er raspelte mehr als (nur) $[\text { Süßholz }]_{\mathrm{Foc}}$ raspelte. (\#Er hat sich he rasped more that just licorice

he has himself richtig an sie rangeschmissen.)

actually at her at-thrown

'He rasped more than just licorice. (\#He actually flinged himself at her.)'

c. Er raspelte (schon den ganzen Tag) Süßholz raspelte (um die alte he rasped already the whole day licorice for the old Dame zum Verkauf zu bewegen).

lady to the sale to persuade

'He has been sweet-talking the whole day to persuade the old lady to sell.'

This discussion showed that the restriction on movement out of the surface scope of operators such as mehr als 'more than' is so general that it applies to all syntactic categories. Second, the restriction is not a general ban on movement: Move- 
ment of a part of the predicate, such as the verbal stem of the particle verb in (17b), is possible. Third, the restriction only excludes movement of the whole focus exponent or parts of a non-compositional element because no meaningful alternatives can be computed for empty elements or non-compositional parts. In essence, even though V2-movement is constrained by this restriction, it is not V2-specific.

\subsubsection{Internal constraint: Morphological dilemmas of complex verbs}

Two different classes of immobile verbs can be distinguished in German (and Dutch). These are double-particle verbs and back-transformations. In contrast to the examples of the previous section, the constraint on movement arises from the internal (morphological) structure of the respective predicates. Both classes involve a morphological dilemma because the relevant verbs cannot be split up and cannot move as a whole (Haider 1993: 65).

In V2-contexts, German particle verbs split the verbal stem from the particle. The finite verbal part moves to the V2-position and the particle remains behind, as illustrated in (20).

(20) an-kündigen 'announce' (lit. 'on-announce')
a. ... dass du uns ankündigst
that you uns on.announce
'... that you announce us'

b. Du kündigst $t_{1}$ uns an- $t_{1}$.

you announce us on

'You announce us.'
c. ${ }^{\star}$ Du ankündigst ${ }_{1}$ uns $t_{1}$. you on.announce us

There are a few particles, such as vor 'before' that combine productively with verbs, even with verbs which are already particle verbs. The result is a double particle verb with two adjacent particles, such as vor-an-kündigen 'pre-announce' in (21a). These verbs induce a dilemma in V2-environments: The verb cannot move alone, leaving behind both particles (21b), nor can any of the particles move with the verb (21c-21d), nor can both particles move with the verb (21e), nor can the V2-constraint be ignored and the verb remain in-situ (21f) (Haider 2010: 58-61).

(21) a. ... wenn du uns vorankündigst.

if you us pre-announce

'... if you pre-announce us.'

b. * Du kündigst ${ }_{1}$ uns vorankündigst ${ }_{1}$.

c. * Du ankündigst ${ }_{1}$ uns vorankündigst ${ }_{1}$. 
d. * Du vorkündigst ${ }_{1}$ uns ๒ørankündigst . $_{1}$.

e. ${ }^{\star}$ Du vorankündigst ${ }_{1}$ uns vorankündigst ${ }_{1}$.

f. * Du uns vorankündigst.

(see Haider 2010: 60)

Haider (2010: 60-61) lists a number of other combinations to illustrate the productiveness of the pattern, see (22).

(22) a. vor + abdrucken $\rightarrow$ vorabdrucken 'preprint' (lit. 'pre-off-print')

b. vor + anmelden $\rightarrow$ voranmelden 'preregister' (lit. 'pre-an-nounce')

c. um + einteilen $\rightarrow$ umeinteilen 'reorganize' (lit. 're-in-deal')

Haider (2010: 61) also includes examples (23a) and (23b) featuring the initial particle mit 'with'. Such examples are exceptional because mit is a rather free particle which is located in the right periphery of the middle field (see Bücker 2012: 209214 for a characterization). ${ }^{4}$ The exceptional status is exemplified in (24), showing that mit can easily separate from the particle verb without giving rise to this dilemma.

(23) a. mit + einsteigen $\rightarrow$ miteinsteigen 'get on together' (lit. 'with-in-step')

b. mit + ausdrucken $\rightarrow$ mitausdrucken 'print out jointly' (lit. 'with-outprint')

(24) a. Dann steigt doch einfach mit-einsteigt.

then step PRT simply with-in

'Then simply get on together (with the others).'

b. Andrea druckt mir das bereits mit-ausdruckt.

Andrea prints for me that already with-out

'Andrea prints this already for me (jointly with her stuff).'

Moreover, mit 'with' may also attach to doubly prefixed verbs as shown in (25). As expected, the resulting complex is unproblematic in V-final position as in (25a), but results in the same dilemmatic situation in (25b) as the doubly prefixed verb alone. Additionally, mit must always be the leftmost particle in such constructions. $^{5}$

(25) mit + voranmelden 'jointly preregister' (lit. 'with-pre-announce')

4 Sebstian Bücking (p. c.) made me aware of this with his talk at the Universität zu Köln, 10 January 2018.

5 If the meaning allows it, the particle mit may occur two times, as in (i), even though this construction is marked because the simpler form with only one mit would suffice in this case. 
a. Kannst du mich morgen bitte mit-voranmelden? Ich hab keine can youme tomorrow plaese with.pre.an.nounce I have no Zeit.

time

'Can you preregister for me too tomorrow? I don't have time.'

b. * Meldest du mich morgen bitte mit-voran? Ich hab keine Zeit. nonce you me tomorrow plaese with-pre.an I have no time 'Can you preregister for me too tomorrow? I don't have time.'

I cannot think of a plausible reason why the movement of the finite verb stem should be constraint directly. An explanation of this immobility must rather focus on the clause-final position: Somehow it seems possible to strand one verbal particle alone, but not two particles together (Haider 2010). Clearly, this account remains rather descriptive, which, however, suffices for now.

The second class of verbs, pseudo-compounds, shows a very similar pattern (Freywald \& Simon 2007). ${ }^{6}$ All of these lexemes have a verbal head, the rightmost constituent in German. The first constituent can be of various categories, as shown in (26). The examples illustrate that the verbal lexemes are derived from nominal forms that contained a deverbal head. This modified head is back-transformed ${ }^{7}$, which results in a complex verb.

a. $\mathrm{N}+\mathrm{V}$

$$
\begin{aligned}
& \begin{array}{l}
\text { Gen+manipulation } \rightarrow \text { genmanipulieren } \\
\text { gene+manipulation } \\
\text { gene.manipulate }
\end{array} \\
& \text { 'genetic engineering' } \rightarrow \text { 'do genetic engineering' }
\end{aligned}
$$

b. $\mathrm{V}+\mathrm{V}$

$$
\begin{aligned}
& \text { Mäh+drescher } \rightarrow \text { mähdreschen } \\
& \text { mow+thresher mow.thresh } \\
& \text { 'harvester' } \rightarrow \text { 'use the harvester' }
\end{aligned}
$$

(i) Wenn du eh schon zum Kiosk gehst, kannst du mir dann auch noch was if you PRT already to the kiosk go can you me then also something mit-mitbringen? with-with.bring 'If you are going to the kiosk anyway, could you bring also something for me?'

6 An observation that dates back to Höhle (2018: 370-372).

7 Freywald \& Simon (2007) differentiate between back-conversion and back-transformation. The only difference is that in conversion no affix is added or removed. 
c. $\mathrm{A}+\mathrm{V}$

Erst+wähler $\rightarrow$ erstwählen

first+voter first.vote

'first-time voter' $\rightarrow$ 'vote for the first time'

d. $\mathrm{P}+\mathrm{V}$

Zwischen+landung $\rightarrow$ zwischenlanden

between+landing between.land

'stopover' $\rightarrow$ 'stop over'

(Freywald \& Simon 2007: 2-3)

However, as illustrated in (27), not all back-transformed verbs are immobile (Fortmann 2007).

(27) a. Theo gewährleistet seine pünktliche Ankunft.

Theo warranty+supplies his punctual arrival

'Theo ensures his punctual arrival.'

b. Eberhardt handhabt Messer und Gabel mit einigem Geschick.

Eberhardt hand+has knive and fork with considerable skill

'Eberhardt handles knive and fork with considerable skill.'

c. Man schlussfolgert oft das Falsche.

one conclusion+deduce often the wrong

'One often reaches the wrong conclusion.'

(Fortmann 2007: 9)

Moreover, Freywald \& Simon (2007) present results from a questionnaire study indicating that some of the alleged immobile verbs are not categorically refused by native speakers. Some of them are rated almost as good as the unproblematic clause-final variants. Additionally, the decision concerning the (non-)separability of the two constituents of the pseudo-compound seems to be influenced by the category of the first constituent. Prepositions, as in (26d), are more likely to be separated and remain in the clause-final bases position. This is not surprising, considering that the particles of most classical particle verbs are at least homophone variants of prepositions. Furthermore, Freywald \& Simon (2007) report that their participants divide into two groups, one accepting back-transformations in V2-contexts and others do not. It seems plausible that the speaker community establishes an acceptance for some verbs, as the ones in (27), over time. ${ }^{8}$

8 The verb teilnehmen 'partake' (lit. part+take) seems to be a case in point that most probably results from a back-transformation. Splitting the nominal part, as illustrated in (i), is completely unmarked. 
Therefore, the immobility of pseudo-compounds can be reduced to the assumption that the lexical entry of the verbs in question is somewhat defective, which only surfaces when the speaker has to make a decision about separating the verb stem from the modification or not. It also appears possible that lexemes that are currently immobile become mobile in the future.

Comparable cases of immobility of the finite verb due to multiple particle prefixing and back-transformation are also observed in Dutch (Booij 1990, Koopman 1995). However, Vikner (2005) points out that immobile complex verbs are non-existent in Danish despite Danish being a V2-language. He argues that such immobility only occurs in OV-languages like Dutch and German. Vikner (2005) attributes this difference between VO and OV languages to the linearization differences of the resulting phrases. In German and Dutch, particle verbs and backtransformation exhibit a head-final structure, [PRT $<\mathrm{V}]$ and $[\mathrm{N}<\mathrm{V}]$, because the VP and noun composition is head-final. In Danish, noun composition is also head-final resulting in $[\mathrm{N}<\mathrm{V}]$-structured back-transformations. Danish particle verbs, on the other hand, show a $[\mathrm{V} \prec \mathrm{PRT}]$ pattern due to the VP being head-initial. Interestingly, however, double-particle verbs in Danish show a [PRT $<\mathrm{PRT}<\mathrm{V}]$ order, which resembles the linearization of noun composition (including backtransformation) and distinguishes double-particle verbs formally from particle verbs. The head-final complexes, back-transformation and double-particle verbs therefore form an inseparable word that moves always as a whole. In V2-contexts, normal particle verbs in Danish split up but retain their relative order $(\mathrm{V}<\mathrm{PRT})$, in contrast to German and Dutch. In conclusion it seems that in OV-languages like German and Dutch, the uncertainty of the morphological status is caused by the form identity of the output of morphological and syntactic processes in these languages. ${ }^{9}$

In sum, internal constraints on V2-movement have been identified as conditions on the morphological form, which can be paraphrased as follows: V2movement is not restricted but the outcome may violate constraints on the morphological representation. We have seen that back-transformations are not categorically excluded from V2-movement and may show each of the two options, movement as a complex or splitting up. Furthermore, it can be expected that the

(i) Er nahm an der Veranstaltung teilnahm.

he took at the event part

'He partook in the event.'

9 Following the structure building account of Haider (2012), modification of head-initial phrases is restricted to a single element whereas the modification of head-final phrases is basically unbounded. Multiple-particle verbs are therefore excluded in verb-initial languages. 
status of back-transformed lexemes changes over time and that they "develop" unmarked mobility. The comparison with Dutch as another OV-language and Danish as an VO-type V2-language suggested that the OV-property is an important factor for the phenomenon of immobile verbs. In comparison to the generalized ban on movement in the comparative configuration, which was discussed in the previous section, the problems of this section are specifically tied to V2-movement: The separation of verbal parts and particles arises only under head movement. Movement of non-finite forms into the prefield are fine, as shown in (28).

(28) a. Voranmelden kannst du dich ja trotzdem voranmelden kannst. preannounce can you yourself PRT anyway

'You could preannounce yourself anyway.'

b. Genmanipulieren dürfen wir nur wenige Planzen genmanipulieren do genetic engineering may we only few plants dürfen.

'We are allowed to do genetic engineering only with few plants.'

\subsubsection{Summary}

I presented two types of restrictions on verb movement, an external and an internal constraint. The external constraint is a generalized ban on moving elements out of a comparative construction if the result is an exponent that does allow the computation of meaningful focus alternatives. This restriction turned out to be not V2-specific because it applies to phrasal movement and head movement alike, applies to other syntactic categories apart from verbs, and is also observed in non-V2 languages. The internal constraint is a specific consequence of applying head movement to double-particle verbs and back-transformations. Such movement leads to separation of the verbal part, stranding the remaining part in the V-final base position. This (non-)separation may lead to conflicts of morphological requirements thereby rendering the output of the head movement unacceptable. Such conflicts seem only to arise in V2-languages of the OV-type like German and Dutch.

I conclude that V2-movement is generalized movement. In specific cases its application can conflict with well-formedness conditions of other grammatical areas. Crucially, however, V2-movement cannot be suspended in those cases. Instead speakers are forced to insert an auxiliary to avoid movement of the problematic element, as in (29b). In any case they can never use the finite verb in the clause-final base position of the matrix clause, as in (29c). 
(29) a. ?/??/^ Wir genmanipulieren diese Pflanze genmanipulieren. we genetic engineer this plant

'We modify this plant by genetic engineering'

b. Wir haben diese Pflanze genmanipuliert haben. we have this plant genetic engineered 'We modified this plant by genetic engineering'

c. * Wir diese Pflanze genmanipulieren. we this plant genetic engineer

'We modify this plant by genetic engineering'

\subsubsection{Restrictions on prefield elements}

Above, I stated that any phrasal element may occupy the prefield. This generalization has to be qualified in two ways. In this section, I will show that some phrasal elements may not occupy the prefield, which seems to be subject to crosslinguistic variation. Cases in which apparent non-phrasal elements occur in the prefield will discussed in Section 2.2.

\subsubsection{Negation}

In German, negation is excluded from topicalization, as shown in (30a). It can only appear in the prefield as part of a larger constituent such as the VP, as in (30b).

(30) Christopher hat das Buch nicht gelesen.

Christopher has the book not read

'Christopher hasn't read the book.'

a. * Nicht $t_{1}$ hat Christopher das Buch nicht 1 gelesen. not has Christopher the book read

b. [Das Buch nicht gelesen $]_{1}$ hat (nur) Christopher das Buch nicht gelesen ${ }_{1}$. the book not read has only Christopher

'(Only) Christopher didn’t read the book.'

Cross-lingustic comparison indicates that negation is not generally excluded from the sentence-initial position in V2-languages. In Swedish, negation can appear in preverbal position in declarative rejections, as in (31b), and in rejection questions, as in (32b). The difference in the felicity conditions between the unmarked position of the negation and the preverbal occurrence is far from trivial and the reader is referred to Seeliger (2015). Fronting of the negation is also possible in Icelandic, Norwegian, and Breton (Holmberg 2015: 350). 
(31) SwEDISH: Rejections

a. Han kommer inte till mötet. he comes not to the.meeting 'He isn't coming to the meeting.'

b. Inte kommer han till mötet. Not comes he to the.meeting 'He isn't coming to the meeting.'

(Seeliger 2015: 576)

(32) SwEDISH: Rejecting questions

a. Han kommer inte till mötet?

He comes not to the.meeting

'Surely he isn't coming to the meeting?'

b. Inte kommer han till mötet?

Not comes he to the.meeting

'Surely he isn't coming to the meeting?'

(Seeliger 2015: 576-577)

Zeijlstra (2013) discusses two constructions in Dutch in which the negation can be topicalized, as shown in (33). ${ }^{10}$

(33) DuTch

a. Ik had wel gezien dat Jan aankwam, maar niet ${ }_{1}$ had ik niet gezien dat $_{1}$ I had PRT seen that Jan arrived, but NEG hadI seen that Eddy vertrok.

Eddy left

'I did see that Jan arrived, but I didn't see that Eddy left.'

b. Niet moeten in de lijstworden aangekruist de planten die je al NEG must in the list be crossed the plants thatyoualready hébt.

have

'You must not mark the plants on the list that you already have.'

(Zeijlstra 2013: 893-894)

In O'odham (Papago), an OV-V2 language, the negation can also fill the prefield and precede the auxiliary, as in (34b). Interestingly, in contrast to German ${ }^{11}$, the non-finite verb cannot be placed into the prefield and precede the negation, as in

10 Thanks to Heiko Seeliger (p.c.) for pointing that out.

11 An acceptable German equivalent is given in (i). 
(34c), whereas example (34d) shows that fronting the verb is fine, without (crossing) the negation (Zepeda 1983: 8-9). ${ }^{12}$

(34) O’ODHAM

a. ['I:da 'o'odham]'o pi ñeok.

this person AUX NEG speaking

'This person is/was not speaking.'

b. Pi 'o 'i:da 'o'odham ñeok.

NEG AUX this person speaking

'This person is/was not speaking.'

c. ^Ñeok 'o pi 'i:da 'o'odham .

speaking AUX NEG this person

'This person is/was not speaking.'

d. Ñeok 'o 'i:da 'o'odham.

speaking Aux this person

'This person is/was speaking.'

(Zepeda 1983: 8-9)

Three different explanations could cover these cross-linguistic differences: First, negation might be phrasal in some languages, such as Swedish and O'odham, whereas it is non-phrasal in others, such as German. This would allow to maintain the restriction that only phrasal elements occur in the prefield. Second, we might assume that negation is phrasal in all languages and there are independent reasons that restrict negation from being topicalized in German. Third, we might assume that negation is non-phrasal in all languages but there is a mechanism that exceptionally allows topicalization of these elements in languages such as Swedish and O'odham. I leave this open to future research but will come back to this issue in the summary below.

\subsubsection{Discourse particles}

Discourse particles in German cannot appear in the prefield (Zimmermann 2011: 2029, Bayer \& Struckmeier 2017b: 7). This is illustrated for the discourse particles

(i) Gesprochen ${ }_{1}$ hat diese Person nicht gesprochen 1 . spoken has this person not

'This person has not spoken.'

12 It seems that the negation pi in O'odham has its base position right-adjacent to the second position auxiliary. Additionally, there seems to be a requirement that the negation must precede their target (see Zepeda 1983). 
wohl and doch in (35a) and (35b). In contrast to negation, discourse particles do not move to the prefield as part of a larger unit either, as shown in (36).

(35) Christopher hat wohl/ doch seinem Vater zugehört.

Christopher has PRT PRT his father to-listen

'Christopher listened to his father.'

a. * Wohl hat Christopher seinem Vater zugehört. PRT has Christopher his father to-listen

b. * Doch hat Christopher doch seinem Vater zugehört. PRT has Christopher his father to-listen

a. * [Wohl/ Doch seinem Vater] hat Christopher wohl/doch seinem Vater PRT PRT his father has Christopher zugehört. to-listen

b. *[Wohl/ Doch seinem Vater zugehört] hat Christopher wohl/doch PRT PRT his father to-listen has Christopher seinem Vater zugehört.

Many discourse particles have homophonous counterparts that indeed may occupy the sentence-initial position, as illustrated by the contrast of adverbial vielleicht 'perhaps' in (37) and the discourse particle in (38).

(37) vielleicht as an adverb

a. Renate ist vielleicht in die Oper gegangen

Renate is perhaps in the opera gone

'Perhaps, Renate went to the opera.'

b. Vielleicht ist Renate in die Oper gegangen.

perhaps is Renate in the opera gone

'Perhaps, Renate went to the opera.'

(Bayer \& Struckmeier 2017b: 7, fn. 5)

(38) vielleicht as a discourse particle

a. Díe ist vielleicht eingebildet! she is VIELLEICHT arrogant

'Boy, is shé arrogant!'

b. * Vielleicht ist díe eingebildet! VIELLEICHT is she arrogant

(Bayer \& Struckmeier 2017b: 7, fn. 5) 
Zimmermann (2011: 2029) proposes that German discourse particles cannot appear in the prefield position because they cannot bear stress. This may explain why discourse particles do not appear in the prefield on their own but not why they cannot move as part of a larger phrase, as in (36). Additionally, in questions, discourse particles may be fronted along with the wh-expression, as in (39) (see Bayer \& Trotzke 2015).

(39) a. Wer wohl ist zu spät gekommen?

b. Wie bloß konnte das passieren?

Furthermore, as Zimmermann (2011: 2031-2033) points out, discourse particles may appear in the left periphery in other languages, such as the Swedish particles nog and visst in (40) (see Scherf 2017).

\section{(40) SWEDISH}

Nog/Visst läser Peter tidningen i köket.

NOG VISST reads Peter newspaper.DEF in kitchen.DEF

'Peter reads the newspaper in the kitchen.' (Scherf 2017: 80)

In sum, discourse particles are heavily restricted in their occurrence in the prefield. A possible explanation has been their inability to bear stress. Concerning the cross-linguistic variation it seems not clear if their distribution is due to their phrase structural status, i. e. being a head vs. a phrase.

\subsubsection{Verbal particles}

It is a well-known fact about German and Dutch that particle verbs may split up in V2-environments, moving the finite verb stem into the V2-position and leaving the particle behind, as shown in (41a) vs. (41b). Fronting the particle verb as a whole, as in (41c), is unproblematic, whereas fronting only the particle, as in (41d), is degraded.

(41) a. ... dass der Vater das Buch vorliest. that the father the book reads out

'... that the father reads out the book.'

b. Der Vater liest das Buch vorliest. the father reads the book out 'The father reads out the book.'

c. Vorgelesen hat $_{1}$ der Vater das Buch vorgelesen hat $_{1}$. read out has the father the book

'The father read out the book.' 
d. * Vor $_{2}$ hat $_{1}$ der Vater das Buch vor $_{2}$ gelesen hat . $_{1}$ out has the father the book read

However, as has been noted by Frey (2004) and discussed by Trotzke \& Quaglia (2016) and Trotzke \& Wittenberg (2017), some particle verbs allow an emphatic topicalization of the particle, as shown in (42).

a. Rúnter hat sein Chef ihn vor allen Kollegen gemacht! PRT(down) has his boss him in front of all colleagues made 'His boss put him down/heavily criticized him in front of all his colleagues.' (Trotzke \& Quaglia 2016: 118)

b. Áuf hat Otto die Türe gemacht. PRT(open) has Otto the door made 'Otto opened the door.' (Frey 2004: 32)

Trotzke \& Quaglia (2016) argue that the ability to contrast the fronted particle with an alternative particle plays an important role in understanding this restriction. ${ }^{13}$ In other words, it seems that it is not the syntactic properties that condition the fronting of the verbal particles but the pragmatic properties that are related to the prefield position.

\subsubsection{Weak pronouns and expletives}

In German, the prefield can be filled by a semantically empty expletive es 'there', which is form identical to the neuter pronoun es 'it'. The paradigm in (43) illustrates that the expletive can only appear in sentence-initial position, as in (43a), but not in the middle field, i. e. to the right of the V2-position, as in (43b-43d), or after the complementizer, as in (43e), (den Besten 1983: 66-69, Tomaselli 1986, Speyer 2009).

(43) a. Es kann nur eine Konstituente vor dem finiten Verb stehen. EXPL can only one constituent before the finite verb stand 'Only one constituent may appear in front of the finite verb.'

b. Nur eine Konstituente kann ( ${ }^{\star} \mathrm{es}$ ) vor dem finiten Verb stehen. only one constituent can ExPL before the finite verb stand 'Only one constituent may appear in front of the finite verb.'

c. Wo kann (*es) nur eine Konstituente stehen? where can ExPL only one constituent stand 'Where does only one constituent may appear?'

13 See also the discussion of examples (17b) and (18b) above. 
d. Kann ( ${ }^{\star}$ es) nur eine Konstituente vor dem finiten Verb stehen? can EXPL only one constituent before the finite verb stand 'Does only one constituent may appear in front of the finite verb?'

e. ... dass ( ${ }^{\star}$ es) nur eine Konstituente vor dem finiten Verb stehen that EXPL only one constituent before the finite verb stand kann.

can

'... that only one constituent may appear in front of the finite verb.'

The neuter pronoun es 'it' frequently appears in the prefield if it represents the subject of the main clause verb, irrespective of whether it is a non-referring element such as the subject of weather-verbs in (44) or a referential subject as in (45). The variants in (44b) and (45b) illustrate that these elements may appear in the middle field as well, in contrast to the prefield expletive.

(44) a. Es hat gestern geschneit.

it has yesterday snowed

'Yesterday, it snowed.'

b. Gestern hat es geschneit. yesterday has it snowed

'Yesterday, it snowed.'

(45) a. Es hat auf dem Tisch gelegen.

it has on the table laid

'It laid on the table.'

b. Auf dem Tisch hat es gelegen.

on the table has it laid

'It laid on the table.'

However, it has been observed that the pronoun es may not appear in the prefield if it represents an object, as in (46a), whereas it is fine in the middle field as in (46b) (Travis 1991: 359).

(46) Gestern habe ich ein Buch gekauft.

'Yesterday, I bought a book.'

a. * Es hat mein Vater heute schon gelesen. it has my father today already read

b. Mein Vater hat es heute schon gelesen. my father has it today already read 'My father already read it today.' 
Closer inspection, however, reveals that there are cases, such as (47), where object-es occurring in the prefield is perfectly acceptable (see Lenerz 1994: 162, Frey 2006b, Meinunger 2007).

(47) a. (Gestern binicherstmals ohnmächtig geworden.) Es hat zum yesterdayam I for the first time unconscious become it has to the Glück niemand mitgekriegt.

luck nobody realized

'(Yesterday I fainted for the first time.) (Though) luckily, nobody realized it.'

b. (Wo kommt das Buch her?) Es muss doch jemand dahin gelegt where comes the book from it must PRT someone there put haben.

have

'(Where did this book come from?) Someone must have put it there.'

(Meinunger 2007: 555-557)

That the occurrences of es are not cases of expletive prefield-es can easily be diagnosed by looking at the subordinate clause variants of (47b): As indicated in (48a), the pronoun cannot be left out in the middle field. Moreover, placing the object-es after the subject, as in (48b), results in markedness. I suspect that, in order to form a felicitous answer, the pronoun must receive stress, which it cannot. Replacing it by a stressed DP, as in (48c) is fine again.

(48) Wo kommt denn das Buch her?

Where comes PRT the book from

'Where did this book come from?'

a. Ich vermute, dass *(es) jemand dort verloren hat.

I suppose that it somebody there lost has

'Is suppose that somebody has lost it there.'

b. \#Ich vermute, dass jemand es dort verloren hat.

I suppose that somebody it there lost has

'Is suppose that somebody has lost it there.'

c. Ich vermute, dass jemand das Búch dort verloren hat.

I suppose that somebody the book there lost has

'Is suppose that somebody has lost the book there.'

Meinunger (2007) observed that the crucial factor for the acceptability of objectes in the prefield is the specificity of the subject. With an indefinite unspecific subject as in (49a), object-es is fine but with a definite specific subject as in (49b), it is unacceptable and only the demonstrative das 'that' is acceptable. 
(49) (Wo kommt das Buch her?) where comes the book from

'Where did this book come from?'

a. Das/ Es muss jemand hier verloren haben. that it must someone here lost have 'Someone must have lost that/it here.'

b. Das/ *Es muss der Professor hier verloren haben. that it must the professor here lost have 'The professor must have lost that/it here.'

Similarly, other non-referential pronouns such as the lexical reflexives in (50) and (51) cannot appear in the prefield (see Speyer 2009: $325 \mathrm{fn} .2$ and references therein). ${ }^{14}$
a. Ich habe mich getäuscht/ geärgert.
I have REFL been mistaken been upset
'I was mistaken/upset.'
b. * Mich habe ich geärgert/ getäuscht. REFL have I been mistaken been upset

(51) a. Niemand hat sich das komplett angehört. nobody has REFL that entirely listened to 'Nobody listened to that entirely.'

14 Speyer (2009: $325 \mathrm{fn}$. 2) also claims that object-expletives are banned from the prefield. However, his contrast pair, given in (i.a) and (i.b), is ill-chosen because it features a specific subject. With an indefinite unspecific subject as in (i.c), the object-expletive is fine in the prefield, thereby paralleling the cases with referential object-es discussed above. Example (i.a) shows that the expletive is obligatory also in the middle field.

(i) a. Karl hat * (es) eilig.

Karl has it urgent

'Karl was in a hurry.'
b. * Es hat Karl eilig. it has Karl urgent
c. Es hatte niemand wirklich eilig it had no one really urgent 'No one was really in a hurry.'
d. Niemand hatte ${ }^{*}($ es $)$ wirklich eilig
no one had it really urgen 
b. * Sich hat das niemand komplett angehört. REFL has that nobody entirely listened to

Specific non-argumental dative elements (free datives/Dativus ethicus) are banned from the sentence-initial position too (Wöllstein-Leisten et al. 1997: 37). These datives are obligatorily realized by a weak pronoun (Mollica 2014: 353).

a. Du bist mir ein Schlingel.

you are me.DAT a rascal

'You're such a rascal.'

b. * Mir bist du ein Schlingel.

me.DAT are you a rascal

(see Wöllstein-Leisten et al. 1997: 37)15

The same restriction is observed for a further class of pro-forms: Some verbs which take a clausal complement allow the insertion of the pro-form es 'it' or das 'that' in the matrix clause, as shown in (53a) and (54a). ${ }^{16}$ In (53b), it seems as if the proform es could occupy the prefield. However, the unacceptability of (54b) and the impossibility of the pro-form das in the prefield position in (53c) and (54c) indicate that the es in (53b) must be analyzed as expletive prefield-es, the occurrence of which is known to depend on the lexical verb (cf. Speyer 2009). ${ }^{17}$

15 Wöllstein-Leisten et al. (1997) state that these datives may not appear in the prefield. Their example, given in (i.a), however, is somewhat confusing because they place the dative pronoun in sentence-initial position of an imperative clause. In imperatives, no constituent is allowed to precede the verb (except for heavy emphasis), as illustrated in (i.c) with the adverbial heute 'today'.

(i) a. * Mir fall nicht hin

me.DAT fall not down

b. Fall mir (heute) nicht hin.

fall me.DAT today not down

'Don't fall down (today).'

c. * Heute fall mir nicht hin. today fall me.DAT not down

16 Reis (1997) calls these pro-forms Platzhalter-Korrelate 'placeholder correlates'.

17 Speyer (2009) takes it for granted that the prefield-es in clauses such as (53b) is coreferent with the embedded clauses without providing any diagnostic.

Yvonne Viesel (p. c.) does not perceive the contrasts as unacceptable as indicated in (53) and (54). Moreover she provided example (i.a), which also sound very good to me. However, replacing das 
(53) a. Dem Vater ist $\mathrm{es}_{\mathrm{i}} /$ das $_{\mathrm{i}}$ egal, [dass Christopher zu spät kommt $]_{\mathrm{i}}$. [the father $]_{\mathrm{DAT}}$ is it that equal that Christopher to late comes 'The father doesn't care that Christopher is late.'

b. Es ist dem Vater egal, dass Christopher zu spät kommt.

It is [the father $]_{\mathrm{DAT}}$ equal that Christopher to late comes

'The father doesn't care that Christopher is late.'

c. ??/^ Das $_{\mathrm{i}}$ ist dem Vater egal, [dass Christopher zu spät kommt $]_{\mathrm{i}}$.

It is [the father] $]_{\mathrm{DAT}}$ equal that Christopher to late comes

'The father doesn't care that Christopher is late.'

(54) a. Der Vater hat $\mathrm{es}_{\mathrm{i}} /$ das $_{\mathrm{i}}$ geahnt, [dass Christopher zu spät kommt $]_{\mathrm{i}}$. the father has it that suspected that Christopher to late comes

'The father suspected that Christopher will be late.'

b. ??/^ Es hat der Vater geahnt, dass Christopher zu spät kommt.

it has the father suspected that Christopher to late comes

'The father suspected that Christopher will be late.'

c. ??/^ Das hat der Vater geahnt, dass Christopher zu spät kommt. that has the father suspected that Christopher to late comes

'The father suspected that Christopher will be late.'

The reason why all the above mentioned pro-forms cannot appear in the prefield is that they cannot be accented. Without being stressed, only pro-forms that are the highest elements in the middle field can occupy the prefield via an operation which Frey (2004) calls formal movement. This is the case for object-es with indefinite unspecific subjects. Lexical reflexive pronouns, free datives (Dativus ethicus) and the clausal pro-forms discussed above are never the highest elements of the middle field irrespective of the specificity of the subject. Hence, they can never appear in the prefield, where they must bear stress. Crucially, none of these can

by es results in unacceptability, shown in (i.b), which indicates that the es is rather the prefield expletive than the pro-form of the embedded clause.

(i) a. Das hab ich (doch) geahnt, dass Christopher wieder zu spät kommt. that have I PRT suspected that Christopher again to late comes 'I have suspected that Christopher will be late again.'

b. * Es hab ich (doch) geahnt, dass Christopher wieder zu spät kommt. EXPL have I PRT suspected that Christopher again to late comes 
be stressed, which results in their ban from the prefield. ${ }^{18}$ In essence, weak pronouns are banned from the prefield because the information structural properties of the prefield position require phonological marking in German, which cannot be realized by these elements for lexico-phonological reasons.

\subsubsection{Qualificational adverbs}

Some adverbials that express the degree to which the event depicted by the predicate holds are quite unacceptable in the prefield, as shown in (55)-(57). ${ }^{19}$

(55) a. Damals hat niemand dem Professor ríchtig zugehört back then has no one the professor really listened to 'Back then, no one really listened to the professor.'

b. * Ríchig hat niemand dem Professor (damals) ríchtig zugehört really has no one the professor back then listened to

(56) a. Gestern hast du deinen Bruder káum angeschaut. yesterday have you your brother hardly looked at 'Yesterday you hardly looked at your brother.'

b. * Káum hast du deinen Bruder (gestern) káum angeschaut. hardly have you your brother yesterday looked at

(57) a. Angeblich hat der Torwart dem Spieler vóll ins Gesicht allegedly has the goalkeeper the player right in the face geschlagen.

hit

'Allegedly, the goalie hit the player right in the face.'

b. * Vóll hat der Torwart dem Spieler (angeblich) vóll ins Gesicht right has the goalkeeper the player allegedly in the face geschlagen.

hit

18 The impossibility of carrying stress has been noted for weak referential pronouns (Travis 1991, Frey 2006b, Meinunger 2007), Dativus ethicus (Mollica 2014: 353), and clausal pro-forms (see Reis 1997: 131).

19 Note that kaum can also be used as a temporal conjunction in the sense of 'shortly after', as which it can appear in the prefield as shown in (i). This reading is irrelevant here.

(i) Kaum hast du deinen Bruder angeschaut, da gab es auch schon Streit. shortly after has you your brother looked at, then gave it also already trouble 'As soon as you looked at your brother, the trouble started.' 
The a-examples indicate that those adverbials can be accented in their base position in the middle field. At this time, I must leave open why these adverbs are resistant to topicalization.

\subsubsection{VPs}

VPs can be fronted quite easily in German. However, there seem to be languagespecific restrictions among the V2-languages. In Icelandic, topicalization of the sole verb as well as a VP (verb plus object) is generally impossible (Thráinsson 2007: 344, 349). ${ }^{20}$ Swedish allows VP-topicalization only for certain verb classes like eventives 'read a book' but not for statives like 'know Swedish' (Källgren \& Prince 1989: 48-49).

A general observation is that VP-topicalization is heavily restricted if it targets the subject and the verb in intransitive structures and impossible if this leads to the exclusion of other arguments in (di-)transitive structures, in line with classic assumptions about constituency (see De Kuthy \& Meurers 2003 for German and Bhatt 1994: 42-43 for Kashmiri). Additionally, the subject included in a topicalized VP may not be definite and the middle field must not be empty (Wöllstein-Leisten et al. 1997: 103-104), as illustrated for the unaccusative landen 'land' in the examples in (58b) and (58c). The same contrast is also observable with the impersonal passive in (59) and the unergative verb in (60).

(58) a. ... dass ein/ das Flugzeug gelandet ist. that a the plane landed is

'... that a plane has landed'

b. * [Das Flugzeug gelandet] ist (auf dem roten Platz noch nie). the plane landed is on the red square yet never

c. [Ein Flugzeug gelandet] ist *(auf dem roten Platz noch nie). a plane landed is on the red square yet never

'No plane has ever landed on the Red Square yet.'

(see Haider 1988: 108-109)

(59) a. ... dass ein/ das Flugzeug gesichtet wurde. that a the plane sighted was 'that a plane was seen'

b. * [Das Flugzeug gesichtet] wurde (dort noch nie). the plane sighted was there never yet

20 Thanks to Jóhannes Gísli Jónsson (p. c.) for making me aware of this. 
c. [Ein Flugzeug gesichtet] wurde *(dort noch nie). a plane sighted was there never yet

'No plane was ever seen there yet.'

(see Haider 1988: 108-109)

(60) a. ... dass ein Außenseiter gewonnen hat. that a outsider won has

'... that an underdog has won'

b. * [Dieser Außenseiter gewonnen] hat (dort noch nie). this outsider won has there never yet

c. [Ein Außenseiter gewonnen] hat *(dort noch nie). a outsider won has there never yet

'No underdog has ever won there yet.'

(see Haider 1988: 108-109)

It remains puzzling why some material has to follow the finite verb in the cexamples above because the examples in (61) and (62) show that string vacuous movement of the verb is not ruled out generally. ${ }^{21}$

(61) a. Du spinnst.

you spin

'You're nuts.'

b. ... dass du spinnst that you spin

'... that you're nuts'

(62) a. [Geohrfeigt zu werden] schmerzt. slapped to be hurts

'It hurts to be slapped.'

b. ... dass geohrfeigt zu werden schmerzt. that slapped to be hurts

'... that it hurts to be slapped.'

(Haider 1988: 109)

This descriptive presentation will suffice for now, for syntactic analysis of VP-topicalization see Ott (2018) and references therein.

21 Yvonne Viesel (p.c.) suggested that empty middle fields are acceptable only if a lexical verb appears in the V2-position but not if an auxiliary appears there. This appears to be the correct generalization, however, it remains to be investigated why this leads to a contrast in acceptability. 


\subsubsection{Paratactic clauses}

Generally, embedded clauses can occupy the prefield as illustrated for complement clauses in (63b) and adverbial clauses in (63c).

(63) a. Sicherlich hat Christopher angenommen, dass wir in die Kneipe gehen, surely hasChristopher assumend that we in the pub go weil wir das immer so machen.

because we that always so make

'Surely, Christopher assumed that we will go to the pub because we always do that.'

b. [Dass wir in die Kneipe gehen] hat Christopher angenommen, weil that we in the pub go has Christopher assumend because wir das immer so machen.

we that always so make

c. [Weil wir das immer so machen] hat Christopher angenommen, because we that always so make has Christopher assumend dass wir in die Kneipe gehen.

that we in the pub go

However, some dependent clauses seem to be immobile although they show a typical embedded clause word order, such as the free dass-clauses (Reis 1997: 132-138) in (64).

(64) a. Christopher ist ein Idiot, dass er ihr den Pelzmantel bezahlt hat. Christopher is an idiot that he her the furcoat paid has 'Christopher is such an idiot that he paid for her fur coat.'

b. * [Dass er ihr den Pelzmantel bezahlt hat] ist Chistopher ein Idiot. that he her the fur coat paid has is Christopher an idiot

A similar observation can be made for the non-finite complementizer $u m(z u)$ 'for' and the corresponding finite complementizer damit 'so that': If they introduce final clauses as in (65) and (66), the embedded clauses are completely acceptable in the prefield.

(65) a. Sie nahm den Regenschirm mit, um nicht nass zu werden. she took the umbrella with for not wet to become 'She took the umbrella with her so that she wouldn't get wet.'

b. [Um nicht nass zu werden] nahm sie den Regenschirm mit. for not wet to become took she the umbrella with 
(66) a. Sie nahm den Regenschirm mit, damit sie nicht nass werden she took the umbrella with so that she not wet become würde.

would

'She took the umbrella with her so that she wouldn't get wet.'

b. [Damit sie nicht nass werden würde,] nahm sie den Regenschirm so that she not wet become would took she the umbrella mit.

with

However, if these complementizers introduce a prospective clause, fronting of the dependent clauses is impossible, as illustrated in (67) and (68). ${ }^{22}$

(67) a. Sie stellte den Regenschirm neben sich, um ihn dann am Ende she placed the umbrella next to her for it then at the end doch zu vergessen.

PRT to forget

'She placed the umbrella next to her only to forget it anyway.'

b. *[Um ihn dann am Ende doch zu vergessen] stellte sie den for it then at the end PRT to forget placed she the Regenschirm neben sich.

umbrella next to her

(68) a. Sie stellte den Regenschirm neben sich, damit sie ihn dann am she placed the umbrella next to her so that she it then at the Ende doch vergaß.

end PRT forgot

'She placed the umbrella next to her only to forget it anyway.'

b. *[Damit sie ihn dann am Ende doch vergaß] stellte sie den so that she it then at the end PRT forgot placed she the Regenschirm neben sich.

umbrella next to her

Similarly, V2-complement clauses cannot appear in the prefield, as shown in (69a) and (69b). Example (69c) illustrates that a canonical V-final dass-clause can appear in the prefield in the same environment (see e. g. Reis 1997).

22 Thanks to Łukasz Jędrzejowski (p. c.) for making me aware of the immobility of prospective um zu-clauses. 
(69) a. Jeder ${ }_{\mathrm{i}}$ möchte gern glauben, $\mathrm{er}_{\mathrm{i}}$ sei unheimlich beliebt. everyone wants gladly believe he is.subj weirdly popular 'Everyone $e_{i}$ wants to believe that he $e_{i}$ is extremely popular.'

b. ${ }^{\star}\left[\operatorname{Er}_{i}\right.$ sei unheimlich beliebt] möchte jeder ${ }_{i}$ gern glauben. he is.suBJ weirdly popular wants everyone gladly believe

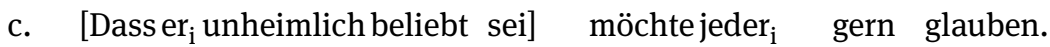
that heweirdly popular is.suBjwants everyone gladly believe

'Everyone $\mathrm{i}_{\mathrm{i}}$ wants to believe that he $\mathrm{e}_{\mathrm{i}}$ is extremely popular.'

(see Reis 1997: 139)

The same argumentation applies also to V2-variants of weil 'because' clauses, as shown by the paradigm in (70) (Frey 2012, Antomo \& Steinbach 2010). ${ }^{23}$

(70) a. Ich komme nicht mit, weil ich habe kein Geld.

I come not with because I have no money

'I will not join you because I have not enough money.'

b. * [Weil ich habe kein Geld] komme ich nicht mit. because I have no moneycome I not with

c. [Weil ich kein Geld habe] komme ich nicht mit. because I no money have come I not with 'I will not join you because I have not enough money.'

I assume that such clausal elements have in common that they are paratactically connected with the main clause. As a consequence, they are not a proper constituent of the main clause and therefore cannot move to the prefield.

\subsubsection{Long-distance elements}

Typically, only constituents of the main clause can appear in the sentence-initial position. This correctly excludes adverbials of embedded clauses (Frey 2004), as shown by the contrast in (71), and extends to recursively embedded clauses, as in (72) and (73).

(71) a. Ich werde ihr mitteilen, dass der Professor gestern nach ihr gefragt I will her tell that the professor yesterday for her asked hat.

has

'I will tell her that the professor asked for her yesterday.'

23 The two variants of weil-clauses do not exhibit the same meaning potential. In addition to the literature cited above see Scheffler (2013: 50-55). 
b. * Gestern $_{1}$ werde ich ihr mitteilen, dass der Professor gestern 1 nach Yesterday will I her tell that the professor for ihr gefragt hat. her asked has

(72) a. Jedoch kann ich noch nicht glauben, [dass Christopher uns however can I still not believe that Christopher us gestern erzählt hat, [dass wir das Haus von Oma erben yesterday told has that we the house of grandma inherit sollen]].

should

'However, I still can’t believe that Christopher has told us yesterday that we should inherit grandma's house.'

b. ??/^[Dass wir das Haus von Oma erben sollen] $]_{1}$ kann ich noch that we the house of grandma inherit should can I still nicht glauben, [dass Christopher uns gestern erzählt hat, $t_{1}$ ]. not believe that Christopher us yesterday told has

(73) a. Also ging die Frau nach Hause, [bevor ihr Bruder husten musste, thus went the woman at home before her brother cough must [weil er sich verschluckt hatte]]. because he REFL choked on had

'Thus the woman went home before her brother had to cough because he choked on something.'

b. * [Weil er sich verschluckt hatte $]_{1}$ ging die Frau nach Hause, because he REFL choked on had went the woman at home [bevor ihr Bruder husten musste $t_{1}$ ]. before her brother cough must

However, long-distance extraction is possible for wh-elements as in (74a), degraded for NPs as in (74b), and strongly degraded for VPs as in (74c), (see Müller 2004). Additionally, such long-distance extractions have been intensively discussed under the term Syntactic Islands. It became clear that the overall acceptability of such structures depends on the clause type (see Freitag 2012 and references therein) and is also subject to dialectal variation (Fanselow \& Weskott 2010).

(74) a. Wen $\mathrm{W}_{1}$ hast du gedacht, dass der Schlagzeuger wen w $_{1}$ geküsst hat? who.Acc have you thought that the drummer kissed has 'Who did you think that the drummer had kissed?' 
b. ?/?? [Die Jule $]_{1}$ habe ich gedacht, [dass der Schlagzeuger the Jule ${ }_{1}$ the Jule have I thought that the drummer geküsst hat]. kissed has 'I thought that the drummer had kissed Júle.'

c. ??/^[Die Jule geküsst $]_{1}$ denke ich, [dass der Schlagzeuger gestern the Jule kissed think I that the drummer yesterday die Jule geküsst ${ }_{1}$ hat].

has

'I thought that the drummer had kíssed Júle yesterday.'

(see Müller 2004: 201-203)

In sum, some constituents of more deeply embedded clauses are able to move to the prefield. However, long-distance extraction is very restricted.

\subsubsection{Summary of licit prefield elements}

The discussion revealed that the prefield position is a proper syntactic position that must be filled in declarative clauses, as a last resort option even by a semantically empty expletive. Typically any main clause constituent may occupy this position. The restrictions on prefield elements can be divided into three major groups. First, paratactic clauses and constituents of lower embedded clauses are forbidden because they do not count as constituents of the main clause. Furthermore, the sentence-initial position is strongly related to an information structural position of the sentence topic or emphatic contrast. This accounts for the second type of restriction: If an element cannot function as a topic or does not employ a meaningful contrast, the element is infelicitous in the prefield, such as certain verbal particles and presumably qualificational adverbs. The third type of restriction is directly related to the special interpretation of this position: If the element in question is not the highest element in the middle field, it cannot move to the prefield without bearing stress. Weak pronouns cannot bear stress and can therefore only move to the prefield if they are the highest element of the middle field. Three phenomena that have been discussed are not covered by these explanations. These are negation, discourse particles and VP-topicalization. For each of these elements I have noted that there is cross-linguistic variation among the V2-languages whether these elements are allowed in the prefield or not. This indicates that the restrictions are rather language-specific and not a direct property of the V2-configuration as such. I must leave the explanation of these elements for future research. 


\subsection{Exceptions: Non-V2 structures}

Exceptional non-V2-structures come in three main categories: first, clauses with an empty prefield, second, independent clauses in which the finite verb does not move at all, i. e. V-final main clauses, and third, clauses in which more than one constituent appears in the prefield, before the fronted verb.

\subsubsection{V-initial clauses}

In addition to polar interrogatives, German also exhibits declarative clauses with V1-order. Two forms must be distinguished. The first is the result of Topic Drop (see Oppenrieder 2013: 36-39, Trutkowski 2016). As shown in (75a), an argument can be left out if it is a salient topic whereas (75b) illustrates, that deletion of the same element is illicit in the middle field. Hence these structures are underlyingly proper V2-clauses.

(75) Was ist mit den Weingläsern?

'What about the wine glasses?'

a. Die Hab ich schon auf den Tisch gestellt. them have I already on the table placed

'I've already placed them on the table.'

b. * Ich hab die schon auf den Tisch gestellt.

I have them already on the table placed

However, German exhibits several specific V1-declaratives such as the justification sentence in (76a), which is not only a variant of a V2-clause, as the contrasting example in (76b) shows. Further examples are given in (77) that are typical for narrative style, such as, but not exclusively, jokes (Oppenrieder 2013: 40-42).

(76) Mit dem nahrhaften Blut ihrer Opfer aber schlürfen die Mücken auch Fremdkörper ein, die mitunter eine immunologische Herausforderung sind.

'Together with the nutritious blood of their victims, mosquitoes also suck foreign matter that can be an immunological challenge.'

a. (`Es) Müssen sie sich doch mit ihrem Rüssel durch eine Haut EXPL must they REFL PRT with their proboscis through a skin voller Bakterien bohren.

full of bacteria pierce

'Because they must pierce with their proboscis through a skin full of bacteria.' 
b. Sie müssen sie sich ( ${ }^{\star}$ doch) mit ihrem Rüssel durch eine Haut they must REFL PRT with their proboscis through a skin voller Bakterien bohren.

full of bacteria pierce

'They must must pierce with their proboscis through a skin full of bacteria.'

(Oppenrieder 2013: 40)

(77) a. (\#Es) Kommt ein Mann zum Arzt. EXPL comes a man to the doctor 'A man came to the doctor.'

b. Ich geh heute auf den Markt. (Da) Kostet ein Bund Petersilie 2 Euro. I go today on the market there costs a bunch parsley 2 Euro 'I went to the market today. A bunch of parsley cost 2 Euros.' (see Oppenrieder 2013: 41)

c. $\left({ }^{\star} \mathrm{Es} /{ }^{\star}\right.$ So) Sollen sie ihn (doch) haben.

EXPL so should they him PRT have

'They should have him then.' (see Oppenrieder 2013: 42)

These V1-structures also have specific felicity conditions that correlate with their interpretational properties. Syntactically, they might be treated on a par with other V1-structures, such as polar interrogatives.

\subsubsection{V-final main clauses}

German also exhibits independent clauses in which the finite verb remains in its base position. These either show formal features of interrogative clauses, such the interrogative in (78a) and the exclamative in (78b), or they exhibit a complementizer such as the declarative dass in (79a) or the interrogative ob in (79b). Truckenbrodt (2013) provides arguments against an ellipsis analysis and details about the felicity conditions and the interpretational potential of independent V-final clauses (see also Oppenrieder 2013: 42-43).

(78) a. Was er wohl eingekauft hat? what he PRT bought has '(I wonder) What he might have bought?'

b. Wie schön du doch Klavier spielen kannst. how beautiful you PRT piano play can 'How beautiful you play the piano.' 
(79) a. Dass du mir (ja) nicht zu spät heimkommst! that you me PRT not to late home come

'Don't be late tonight!' (Truckenbrodt 2013: 238)

b. (X: Peter hasn't written in a long time.

Y: That's true.)

$\mathrm{X}: \mathrm{Ob} \quad$ es ihm gut geht?

whether it him well goes

'I wonder whether he is doing well.' (Truckenbrodt 2006a: 261)

All V-final main clauses are formally identical to embedded clauses. Hence, the syntactic structure is comparable to regular embedded clauses in German. Clearly, there must exist a pragmatic mechanism to interpreted these dependent clauses as an illocutionary act, a topic which is well beyond the scope of the present discussion (see Bayer 2004: 84-89).

\subsubsection{V>2 structures}

There are also some structures that (apparently) exhibit more than one constituent before the finite verb. Connectors such as denn, doch, and aber precede the sentence-initial constituent, as in (80), which shows that this also holds for non-subject-initial clauses.

(80) Denn/ doch/ aber [Rosinen] mag Christopher nicht. because however but raisins likes Christopher not

'Because/However/But Christopher doesn't like raisins.'

A different type of complex prefields are discussed in Müller (2003), Müller (2004: 218-219), and Müller (2005), among others. Examples of characteristic patterns are given in (81). It has been noted that the order of the two prefield elements is fixed (Müller 2005: 307-308), that the fronted elements have to be clause mates (Fanselow 1993: 67) ${ }^{24}$, and that the acceptability of examples like (81e) depends on the specificity and definiteness of the fronted DPs (Müller 2004: 218-219). Müller (2005) proposes to analyze the fronted elements as one complex constituent with an empty head, similar to a VP. Under such an analysis, the prefield is only apparently filled with multiple constituents.

24 Note that extraction out of embedded clauses is highly restricted on its own, as discussed in Section 2.1.4.8. 
(81) a. [Fast alles] [im Sitzen] bewältigt Fernando Escartin auf dem almost everything in sitting manages Fernando Escartin on the Weg zum Gipfel fastalles im Sitzten bewältigt. way to the peak

'Fernando Escartin manages handles almost all passage on it way to the peak seated.' (Müller 2004: 219)

b. [Alle Träume] [gleichzeitig] lassen sich nur selten alle Träume all dream simultaneously let REFL only seldom gleichzeitig verwirklichen łassen. realize

'Only seldom, one can realize all dreams at once.' (Müller 2005: 299)

c. [Zum zweiten Mal] [die Weltmeisterschaft] errang Clark 1965 ... to the second time the world championship won Clark 1965 zum zweiten Mal die Welmeisterschaft errang.

'Clark won the world championship in 1965 for the second time.' (Müller 2005: 300)

d. [Von Konstanz] [nach Bern] wird Urs morgen von Konstanz from Constance to Bern will Urs tomorrow nach Bern fahren drive

'Tomorrow, Urs will drive from Constance to Bern.' (Fanselow 1987: 99)

e. ?? [Kindern] [Bonbons] sollte man KindernBonbonsnicht geben sollte children sweets should one not give

'One should not give sweet to children.' (Müller 2004: 218)

Grewendorf (2013) argues that German provides a principled option of left-dislocating ${ }^{25}$ topic constituents in a position preceding the canonical prefield, as shown for an argument in (82a), also preceding a wh-term as in (82b), and for adverbials in (82c) and (82d). Those initial constituents cannot occupy the prefield. ${ }^{26}$

25 I will exclude so-called hanging topics (nominativus pendens) because they are less integrated into the host clauses (see Shaer \& Frey 2004, Nolda 2004).

26 Though for different reasons: If the sentence-initial DP in (82a) appears in the prefield, the resumptive pronoun must be deleted. The same applies to ( $82 \mathrm{~b})$, in addition to the complementary distribution with the $w h$-term in the prefield. If the adverbial clause in (82c) appears in the prefield, it is preferably interpreted as an integrated conditional clause which results in an implausible interpretation. The initial constituent in (82d) cannot appear in the prefield at all. 


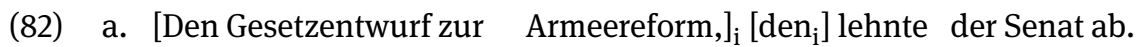
the draft bill to the army reform this refused the senat PRT

'The draft bill of the army reform, the senat refused it.'

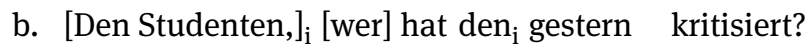
the student who has him yesterday criticized

'This student, who criticized him yesterday?'

c. [Wenn du Durst hast,] [im Kühlschrank] ist ein Bier. if you thirst has in the fridge is a beer

'In case you are thirsty, there's beer in the fridge.'

d. [Wen immer du einlädst,] [ich] komme nicht. who ever you invite I came not

'Whoever you will invite, I will not come.'

(Grewendorf 2013: 655-666, 668)

A phenomenon that looks superficially similar is emphatic topicalization, described in Bayer \& Dasgupta (2016) and illustrated in (83): A constituent of the embedded clause is topicalized in front of the complementizer. As a consequence, the embedded clause must appear sentence-initially. If the analysis of Bayer \& Dasgupta (2016) is correct, the prefield is occupied by only one constituent, an embedded clause with a complex prefield of its own.

(83) BAVARIAN

a. [[Da Hans] [ob da Hans kummt $]]_{1}$ woass-e ned $t_{1}$. the Hans whether comes know-I not

'As for Hans, I don't know whether he will come.' (Bayer \& Dasgupta 2016: 5)

b. [[Der] [wenn der das nochmal macht] $]_{1}$ bin ich echt grantig $t_{1}$. he when this again does am I really pissed

'If he does this again, I'm going to be really pissed.' ${ }^{27}$

Additionally, it has been noted that multiple adverbials can be placed in the prefield, which is known as adverbial stacking and illustrated in (84a) for Swedish and in (84b) for German. The German example also illustrates the restrictions on adverb stacking: First, stacked adverbials show the same (language-specific ordering) as in the middle field. Second, only event modifying adverbials take part in the stacking, i. e. they cannot be accompanied by the epistemic adverbial vermutlich 'pressumably' or the optional argument ein Lied 'a song' although these might

27 From a speaker of Northern Bavarian. 
appear in their base position. Even though the adverbials form separate prosodic phrases, it is commonly assumed that they form a kind of cluster that occupies only a single syntactic position (Haider 2000a: 97-102, Holmberg 2015: 353-354).

\section{a. SWEDISH}

[I går,] [vid femtiden,] [utanför stationen,] [när jag kom från yesterday at about.five outside the.station, when I came from jobbet,] mötte jag en gammal skolkamrat.

work, met I an old schoolmate

'Yesterday, at about five, outside the station, when I came home from work, I met an old schoolmate of mine.' (Holmberg 2015: 353)

b. GERMAN

[Vor zwei Wochen] [in Italien] [am Strand] [als die Sonne before two weeks in Italy at the beach when the sun ungerging] 〈 ${ }^{*}$ vermutlich〉 〈 ${ }^{*}$ ein Lied) hat der Junge 〈vermutlich〉 〈ein sunk presumably a song has the boy presumably a Lied) gesungen.

song sung

'In Italy, at the beach, two weeks ago, before the sun disappeared, the boy presumably sang a song.'

A further form of complex prefield is currently discussed for urban vernacular varieties of German (Kiezdeutsch), Danish, Swedish and Norwegian. ${ }^{28}$ Characteristic for this V3-configuration is that exclusively in subject-initial main clauses, one adverb may precede the subject, as shown in (85). For more details see Wiese (2009), Freywald et al. (2015), Walkden (2017), Bonke (2017). Crucially, the fact that this pattern does not extend to object-initial clauses and that it is not obligatory for subject-initial clauses indicates that it is discourse pragmatically driven and does not represent a novel syntactic structure (see especially Freywald et al. 2015).

(85) NON-STANDARD GERMAN (Kiezdeutsch)

a. [ab jétzt] [ich] krieg immer zwánzig euro

from now I get always twenty euros

'From now on, I get always twenty euros.' (Freywald et al. 2015: 89)

b. [danach] [er] sagt zu O., geh mal wég afterwards he says to O. go PRT away

'Afterwards, he says to O. [=name], go away.' (Walkden 2017: 55)

28 According to Freywald et al. (2015), these structures occur extremely rarely in the corresponding Dutch variant. 
In sum, we have seen that there are several cases in which either complex elements occupy the prefield or an additional element precedes a V2-structure for specific discourse pragmatic reasons. However, all these options are highly restricted.

\subsubsection{Summary of the non-V2 patterns}

In this section, I have presented three classes of deviations from V2-patterns. The first two have been identified as syntactically regular V1-patterns and as embedded clause patterns. What makes them exceptional is not their syntactic structure but their usage as independent utterances. In the third class, apparently more than one constituent precedes the V2-position. Such an extension of the left periphery seems likely for connectors like aber 'but' and left-dislocated elements including the examples from the urban vernacular varieties. For the other form of complex prefields, subsuming emphatic topicalization and adverbial stacking, it seems likely that only one constituent, though a complex one, occupies the prefield.

\subsection{Explanations: A brief history of syntactic accounts}

The core characterization of the V2-phenomenon was already described by Erdmann (1886: 182-185) 29 , who states explicitly that the position preceding the finite verb is not a specific subject position but can be freely occupied by other nouns, adverbials, predicative expressions, or even dependent clauses. This description, however, does not explain how this configuration emerges. In the following, I will focus on the productive line of research based on transformational grammar that assumes that the V2-order is a derived order. Opponents of transformational analyses proposed two unrelated ordering sources for matrix and embedded clause order, for instance Bartsch \& Vennemann (1972), but see Koster (1975) for a principled criticism. But even within the generative grammar, we find a variety of analyses. Ross (1969: 95) for instance proposed that the base word order of German is SVO and the finite verb is moved into the clause-final position in embedded clauses by a movement rule.

29 Reference found in Haider (1985: 49). 


\subsubsection{Insertion into the middle field}

The insight that German (and Dutch) posess a verb-final basic word order is not very old. Bierwisch (1963: 34) acknowledges that Fourquet (1959) was the first who formulated the observation that the order of subordinate clauses is actually the basic configuration from which the orders of main clauses are derived. Fourquet (1959: 139, fn. 6) also argued that there is one structural position in front of the finite verb which can be filled by subjects and non-subjects alike and that a subjectoriented syntax, does not add any explanatory value, as expressed in the following quote:

The rule that the subject is inverted after the verb if the first constituent that precedes the finite verb is not the subject is as insightful as the statement that a motorcyclist in France does not give a German a lift if he already has a non-German on the pillion. It is forbidden by law to have more than one person on the pillion: that is all. ${ }^{30}$

Early transformational grammar approaches for German word order have been more or less simultaneously published by Bach (1962) and Bierwisch (1963), even though the latter is far more extensive. The basic derivation of V2-order, however, is almost identical. Both authors propose to derive the appropriate order by placing the finite verb behind the first constituent (Bach 1962: 269, Bierwisch 1963: 111). ${ }^{31}$ These approaches could therefore be translated as inserting the verb after the highest element in the middle field, i.e. the sub-CP-domain. ${ }^{32}$ That the OVorder is the underlying order and the basis for the transformational rule is motivated by the following observations: All infinitival forms occur in clause-final position as in (86a), and in complex verb forms, only the finite element moves whereas all other elements appear in the clause-final position as in (86b). Fragment answers and lexical mentioning always show verb-final order, as in (86c) and (86d). Furthermore, particles of particle verbs appear in the clause-final position, as in (86e) (see Bierwisch 1963: 35).

30 "Die Regel, daß das Subjekt dem Verb nachgestellt ist, wenn das erste Satzglied, auf das das v.f. [verbum finitum] folgt, nicht das Subjekt ist, hat ebensoviel Wert wie die Feststellung, daß in Frankreich ein Motorradfahrer keinen Deutschen aufnimmt, wenn er einen Nicht-Deutschen auf dem Soziussitz hat: gesetzlich darf er nicht zwei Personen auf den Soziussitz nehmen, das ist alles." (Fourquet 1959: 139, fn. 6, translation C. F.)

31 V1-structures are the result of placing the finite verb behind a phonologically empty element. Interrogatives, imperatives and prefield expletive-es are generated by morphophonemic rules (Bierwisch 1963: 112).

32 It must be noted that a mapping onto a modern sentence skeleton is not unproblematic. 
(86) a. Er versprach einen Teller zu kaufen.

he promised a plate to buy

'He promised to buy a plate.'

b. Er hätte einen Teller gekauft haben sollen.

he had a plate bought have should

'He should have bought a plate.'

c. A: Was machst du?

'What do you do?'

B: Zigaretten holen./ ${ }^{\star}$ Holen Zigaretten.

cigarettes get get cigarettes

'get cigarettes'

d. jemandem etwas schenken/ *jemandem schenken etwas/

somebody something donate somebody donate something

${ }^{\star}$ schenken jemandem etwas

donate somebody something

'donate somebody something (as a present)'

e. Ich höre morgen mit dem Rauchen auf./ *Ich aufhöre morgen I listen tomorrow with the smoking up I up listen tomorrow mit dem Rauchen.

with the smoking

'I will quit smoking tomorrow.'

Additional support for the underlying V-final order comes from verbs that cannot undergo movement to the V2-position, as discussed in Section 2.1.3: All verbs that can appear in V2-position do also appear in clause-final position but not vice versa.

To prevent verb movement in embedded clauses, Bach (1962: 269) included a clause boundary symbol into the definition of the transformation rule by stipulation.

\subsubsection{V-to-C movement (plus phrasal movement)}

Within the sentence skeleton of the X-bar theory, the restriction of V2-movement to main clauses could receive a principled explanation. Emonds (1970: 10-12) noticed that V2 is only one of several syntactic transformations that apply only in root clauses, hence the term root transformations. den Besten (1983) attempted to generalize the notion of root transformations even further and identified two 
crucial insights for the analysis of V2-clauses: First, V2-movement (and likewise all root transformations) targets the clause-initial COMP-position. ${ }^{33}$ The verb thereby moves into a fixed position with the consequence that, in subject-initial clauses, the subject has to be preposed like all other initial constituents. den Besten (1983: 56-60) provides the following arguments in favor of the positional identity of the V2-position and the COMP-position. Weak pronouns in Dutch appear right-adjacent to the finite verb in main clauses and right-adjacent to the complementizer in subordinate clauses. ${ }^{34}$ Additionally, the positional identity of V2 and COMP accounts for the complementary distribution of verb movement and overt complementizer in German and Dutch (den Besten 1983: 17-18). Furthermore, den Besten (1983: 115-117) introduces the idea that verb movement is triggered by a morphosyntactic feature. Motivated by the selectional differences of complementizers like dass 'that', which combines with finite (tensed) VPs, and complementizers like um 'for', which combines with non-finite (untensed) VPs, he labels this feature tense. This labeling is somewhat surprising considering that non-finite forms may express temporal relations and that, in complementizer agreement, only subject-agreement morphemes show up at the complementizer, as den Besten (1983: 119) even notes himself. To account for the movement of the sentence-initial phrase, den Besten (1983: 60-61) formulates a Wh-Movement Rule and a Constituent Preposing Rule in the fashion of the transformational grammar. Generally this mechanism has been retained, even though it is currently assumed that the movement is triggered by specific features on the $C$ head that may be more directly connected to interpretational aspects like in $w h$-questions ${ }^{35}$, or must be formally enforced by an EPP-feature ${ }^{36}$. A simple scheme of the V-to-C analysis is given in (87).

33 As den Besten (1983: 51,107) acknowledges, the idea that V2 is generated by verb movement and (subsequent) movement of one constituent (including the subject) in front of the verb has also been assumed around the same time by Higgins (1973: 152, fn. 5), Williams (1974), Koster (1975), and Emonds (1976: 40).

34 Similar restrictions on the placement of pronouns hold for German too (see Haider 2010: 131141).

35 Following Cheng (1991), movement of a $w h$-phrase into the left periphery is one way to execute clausal typing (see also Brandner 2004).

36 The Extended Projection Principle (Chomsky 1981) captures the observation that some heads (such as I in English) require an overt constituent, in this case a subject, which may also be a semantically empty expletive. A similar regularity holds for the prefield element in V2-languages. In the minimalist framework this EPP-feature corresponds to a strong feature (Chomsky 1995: 232). However, the relatively free choice of constituents which may satisfy this feature in V2-clauses is much more problematic than for subjects. 
(87)

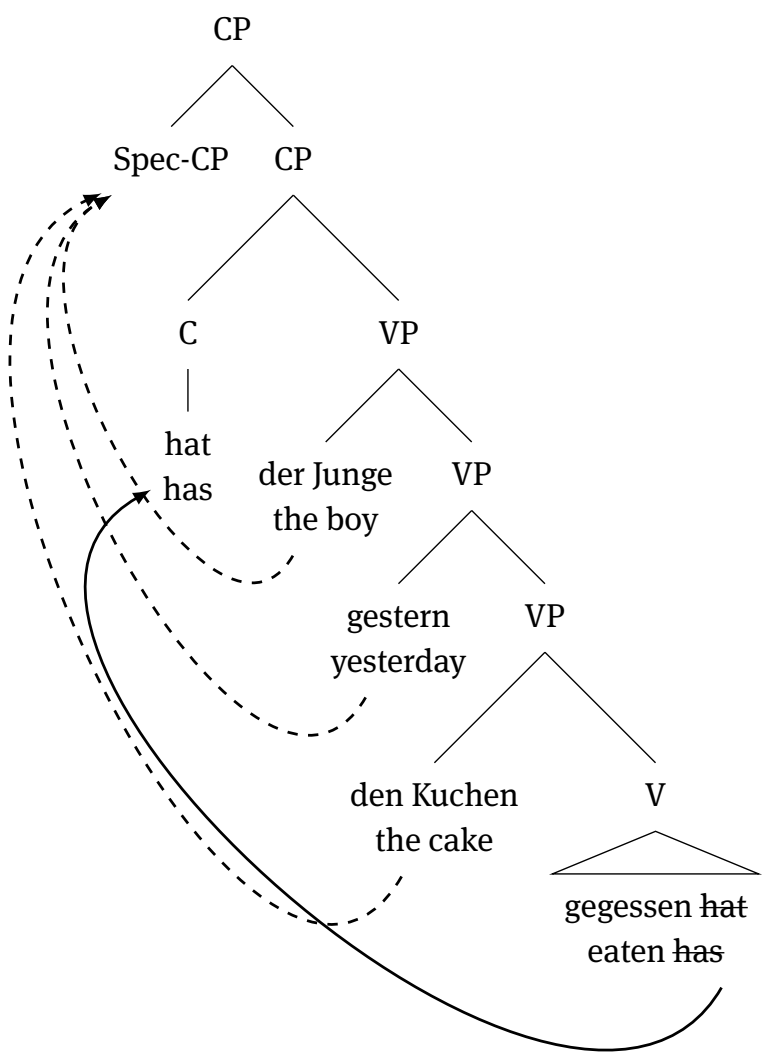

\subsection{3 (A)symmetric V2: V-to-I movement in subject-initial clauses}

Within the Principles and Parameters approach, scholars tried to account for the word order variation within the Germanic V2-languages with different phrase structure parameters, namely V-to-I and I-to-C movement (see e. g. Platzack 1986, Vikner 1995). Some authors have doubted that all V2-clauses are derived by Vto-C movement. Two popular proposals of this kind are Travis (1991) and Zwart 
(1994). ${ }^{37}$ The interesting departure from the traditional analysis is that they assume that V2-movement does not target a uniform position within the clause structure but that subject-initial clauses are generated by movement of the verb to the phrase-initial I-head ${ }^{38}$, as shown in (88). Non-subject-initial clauses are analyzed as V-to-C movement as in the traditional account, as in (89).

(88) Subject-initial clause

a. Der Junge hat gestern den Kuchen gegessen hat. [the boy].NOM has yesterday [the cake].ACc eaten

'The boy has ate the cake yesterday.'

37 These two accounts differ with respect to the headedness of the VP: Travis (1991) assumes a head-final VP for German and Dutch whereas Zwart (1994) assumes a head-initial VP following the antisymmetry approach of Kayne (1994). In a nutshell, Zwart (1994) proposes that the basic underlying word order of Dutch (and German) is SVO, from which a second order, namely SOV is derived by raising the subject and the object to higher functional positions (Spec-AgrObjP and Spec-AgrSubP). Note the criticism of antisymmetry approaches to SOV-languages in Haider (2012).

38 In Zwart (1994), this head is identified as the AgrSubj-head of a split-IP model. 
$54-2$ The Syntax of V2

b.

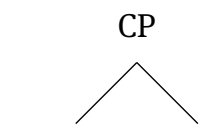

Spec-CP CP

C IP

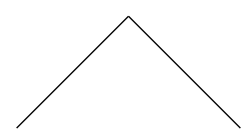

Spec-IP

$\overbrace{\text { der Junge }}$

the boy I

IP

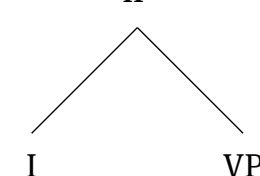

hat
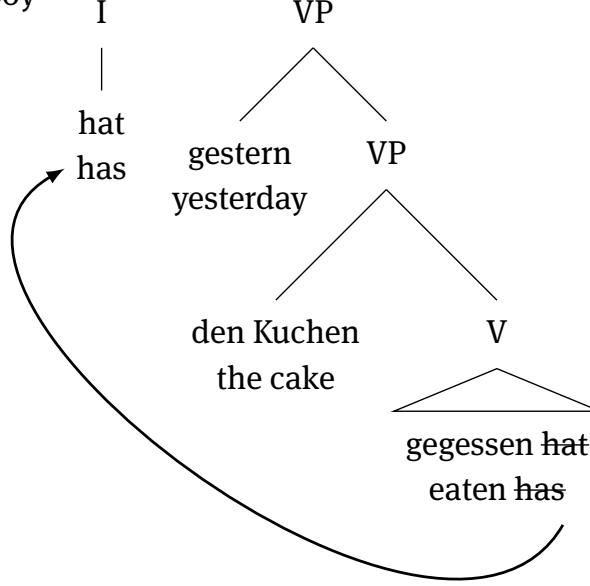
(89) Non-subject-initial clause

a. Den Kuchen hat der Junge gestern den Kuchen gegessen hat. [the cake].Acc has [the boy].Nom yesterday eaten 'The boy ate the cake yesterday.'

b.

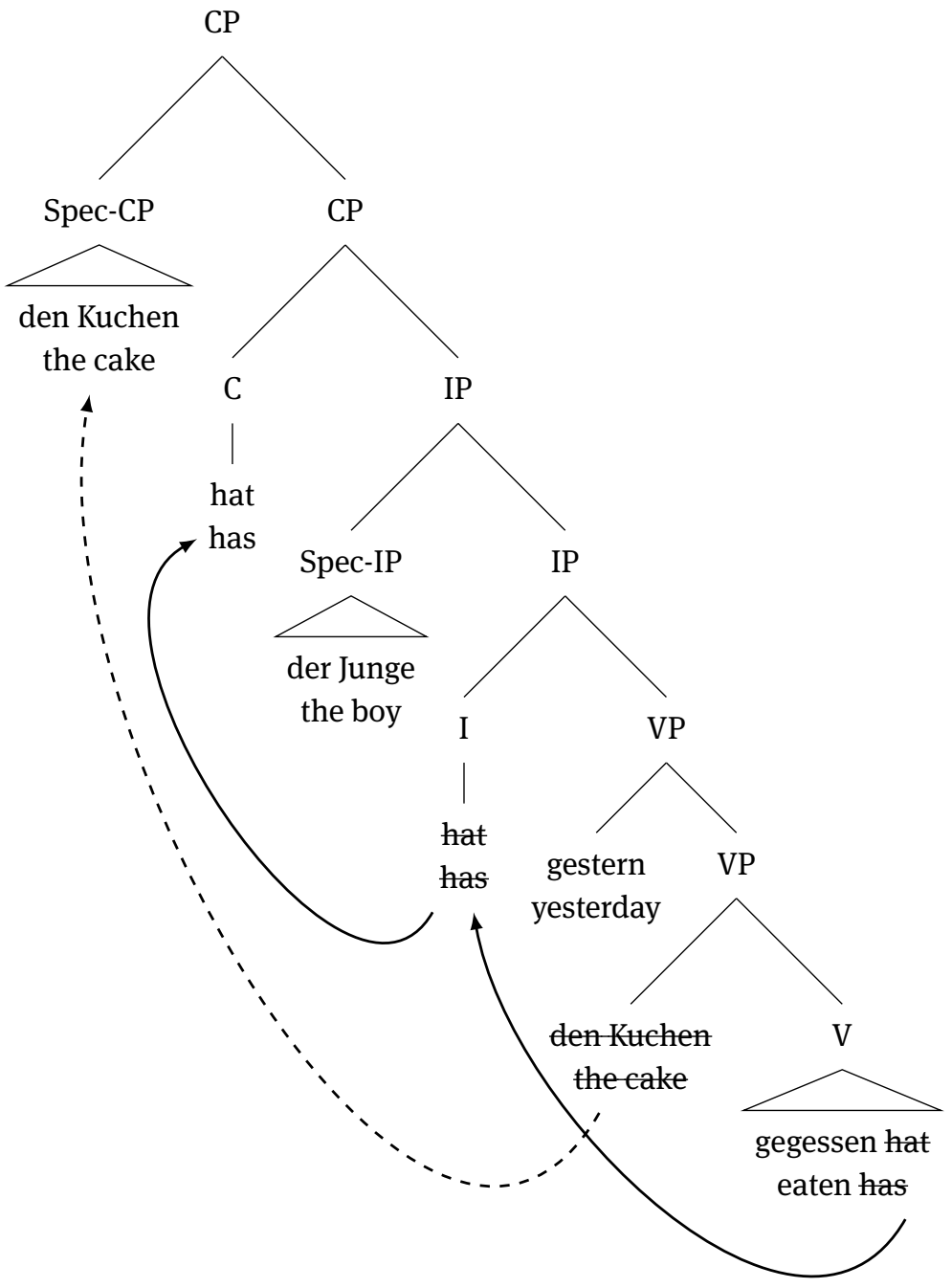

I will not go into detail of the theoretical arguments concerning the contemporary models at that time but rather focus on the empirical arguments in favor of a dis- 
tinction between subject-initial and non-subject-initial clauses (for an extensive discussion with counterarguments see Schwartz \& Vikner 1989 and Schwartz \& Vikner 1996). The main evidence comes from the distribution of clitics and weak pronouns. The observation is that there is an asymmetry that allows weak pronouns to appear in the prefield only if they are subjects and not if they are objects (Travis 1991: 359). The example is illustrated for the neuter German weak pronoun es 'it' in (90). Taking the sentence in (90a) as an illustration of the base order, it is possible to express the subject by a weak pronoun, as in (90b), but unacceptable for the object, as in (90c). As I have discussed in Section 2.1.4.4, this asymmetry is only apparent and depends on the definiteness and specificity of the other arguments in the middle field. As Travis (1991: 359) partly suggests, the problem of putting es into the prefield position seems to correlate with the incompatibility of stressing es. Consequently, changing the sentence as in (90d) allows an unstressed object-es in the prefield. Hence, there is no empirical basis to postulate a more elaborate syntactic structure than the V-to-C model.

(90) a. ... dass das Kind gestern das Buch gelesen hat that the child yesterday the book read hat

'... that yesterday the child read the book.'

b. Es hat gestern das Buch gelesen.

it has yesterday the book read

'Yesterday it read the book.'

c. * Es hat das Kind gestern gelesen.

it has the child yesterday read

'Yesterday the child read it.'

d. Es hat noch niemand gelesen.

it has yet nobody read

'Until now, nobody read it.'

\subsubsection{Two types of V2-movement: Force and Fin}

Following the influential article of Rizzi (1997), the C-domain has been divided into an articulated structure with functional layers, that are related to specific information structural properties on the one hand, such as frame setting, topic, and focus, and two positions that are related to the clause-internal structure and the superordinate structure, namely Fin and Force. Such an articulated periphery may look like in (91). Each of the layers provides a head position and a specifier position. Intuitively, FinP has been associated with V2-movement because 
V2-movement only affects finite verbs. The additional positions have been used to account for systematic extensions of the V2-constraint to V3(+n) structures, especially in North Italian dialects (Poletto 2002) and Medieval Romance (Wolfe 2016). To account for typical V2-languages which provide only one position in front of the finite verb, Poletto (2002) and Wolfe (2016) propose that verb movement targets different final landing sites in those languages: In all V2-languages, in order to check the finiteness feature, the finite verb moves to FinP, which is also the final landing site in Fin-V2 languages. As a consequence, more than one element may precede the moved verb. In Force-V2 languages on the other hand, the Force-head has a strong feature that attracts the finite verb in Fin. Consequently, only frame setters or hanging topics may precede the V2-position (Poletto 2002: 237-238).

(91) [HangingTopic/FrameP $[$ ForceP $[$ TopP $[$ FocP $[$ FinP $[$ TP ... ] ] ] ]]]

The Split-V2 approach offers a way to account for cross-linguistic variation of the number of elements preceding the finite verb in (apparent) V2-languages. However, it does not provide any insight as to why the verb moves and what triggers this movement to FinP. On the contrary, this account introduces a further puzzle, namely a second abstract feature in ForceP that attracts the finite verb in FinP. In sum, we see that in such a two-stage system, we have to duplicate the stipulated trigger for V2-movement which is already problematic in the classical V2-system.

\subsubsection{Remnant movement}

Müller (2004) proposes a remnant movement account for V2 in German. In this account, the V2-configuration does not result from two different movements into the C-domain but from only one phrasal movement operation of vP into Spec-CP. Müller (2004) assumes a structural analysis of a simple German sentences as in (92).

(92) a. (dass) der Junge gestern den Kuchen gegessen hat that the boy yesterday the cake eaten has 'that yesterday, the boy ate the cake.' 
b.

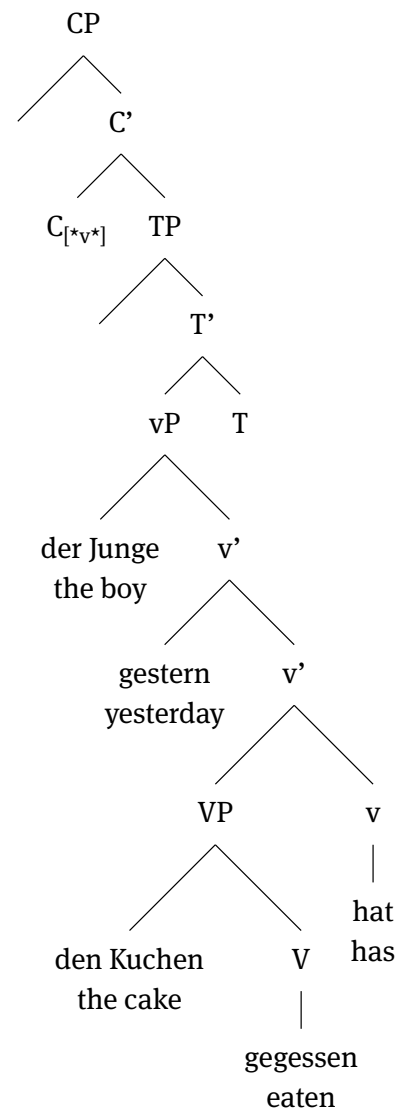

At this stage, all surface constituents are inside vP. Moving vP to Spec-CP would therefore not change the order of the constituents. To obtain the V2-order, all elements that should not appear in the C-domain must be evacuated from vP, as shown in (93). Subsequently, the vP moves to Spec-CP and yields a subject-initial V2-clause, as in (94). 
(93)

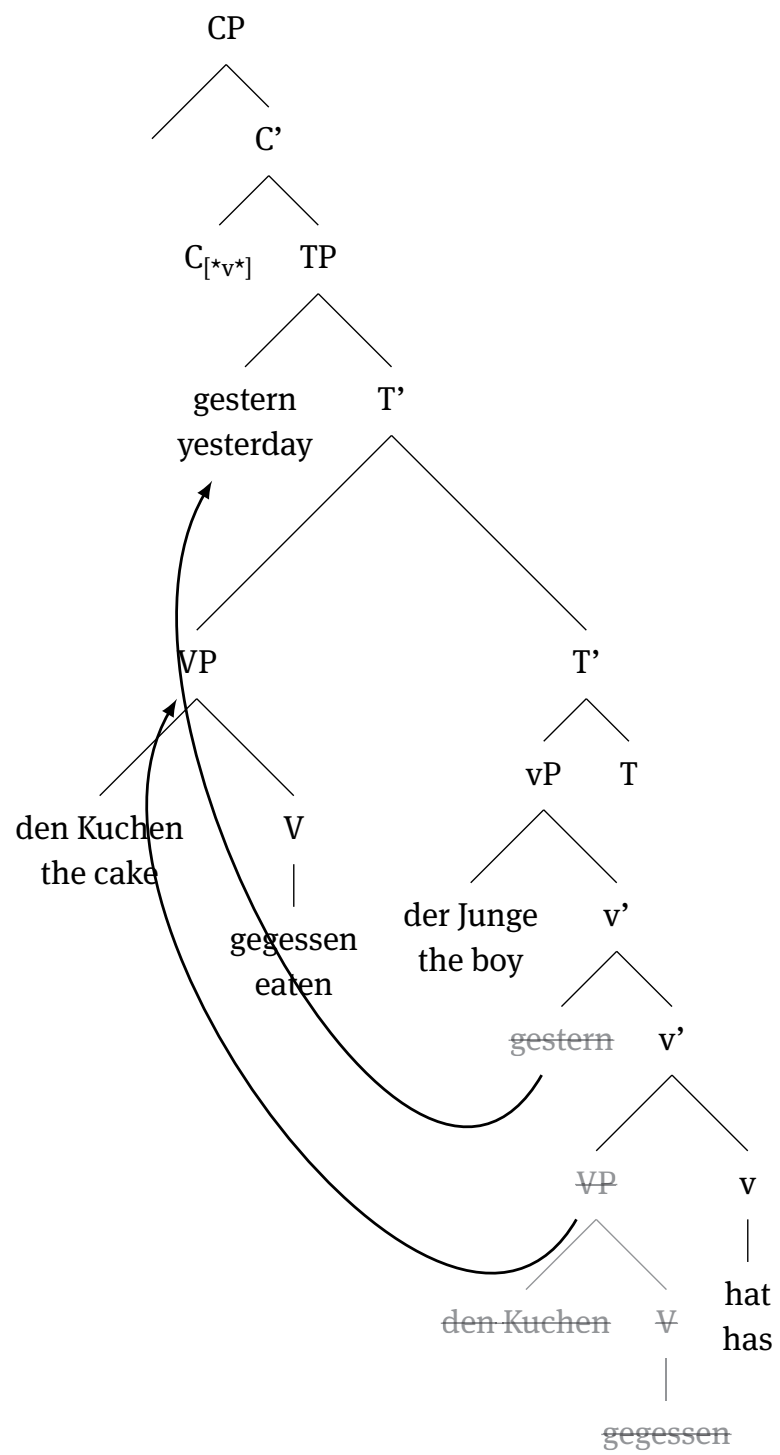


(94)

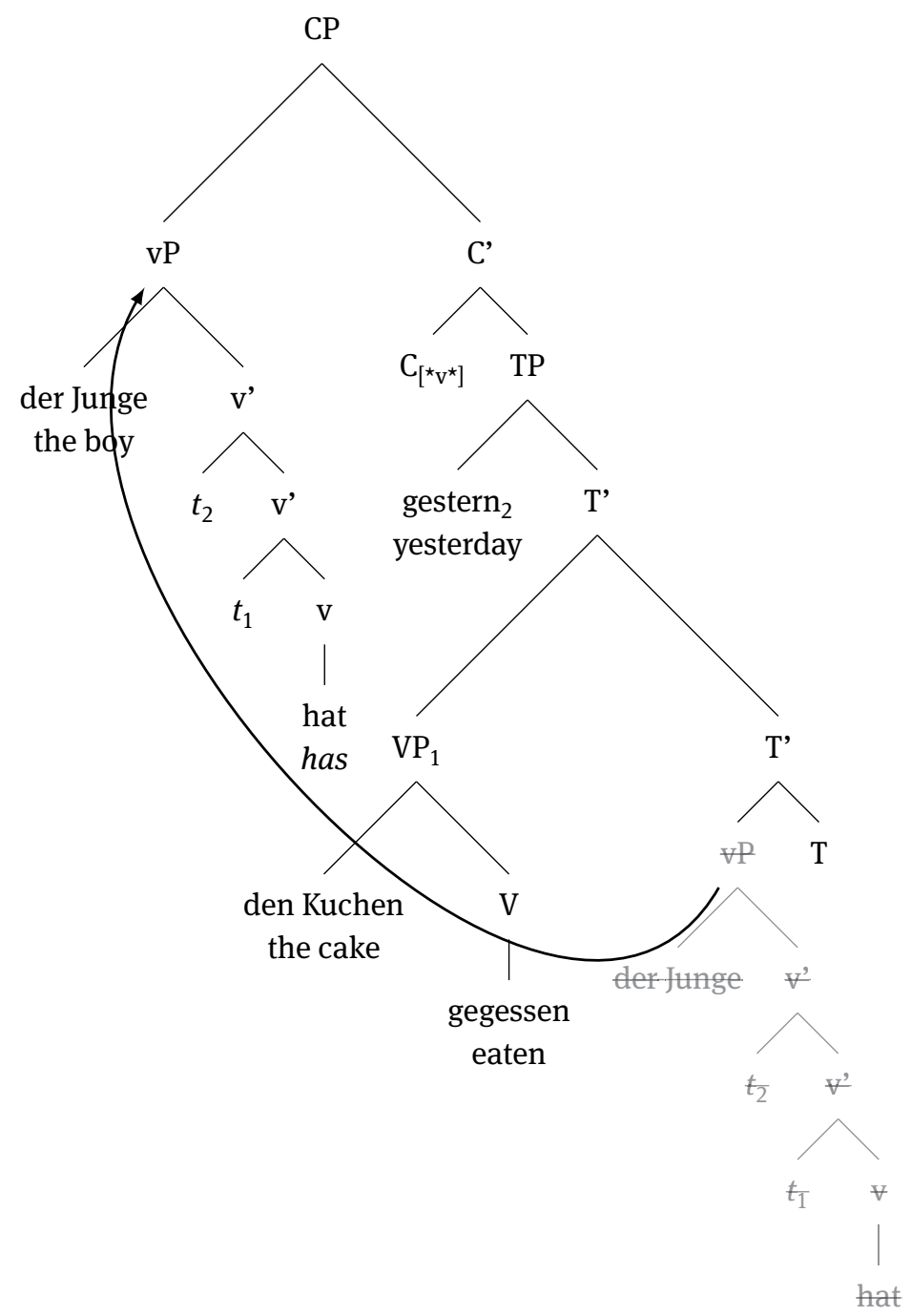

The derivation of object-initial V2-clauses is even more complicated, as shown in (95). Only after a cascade of evacuation movements, the vP is prepared to move to Spec-CP: First, the object is scrambled to the edge of vP. Afterwards, the remaining VP, the adverbial, and the subject are raised to specifiers in the T-domain. 
(95)

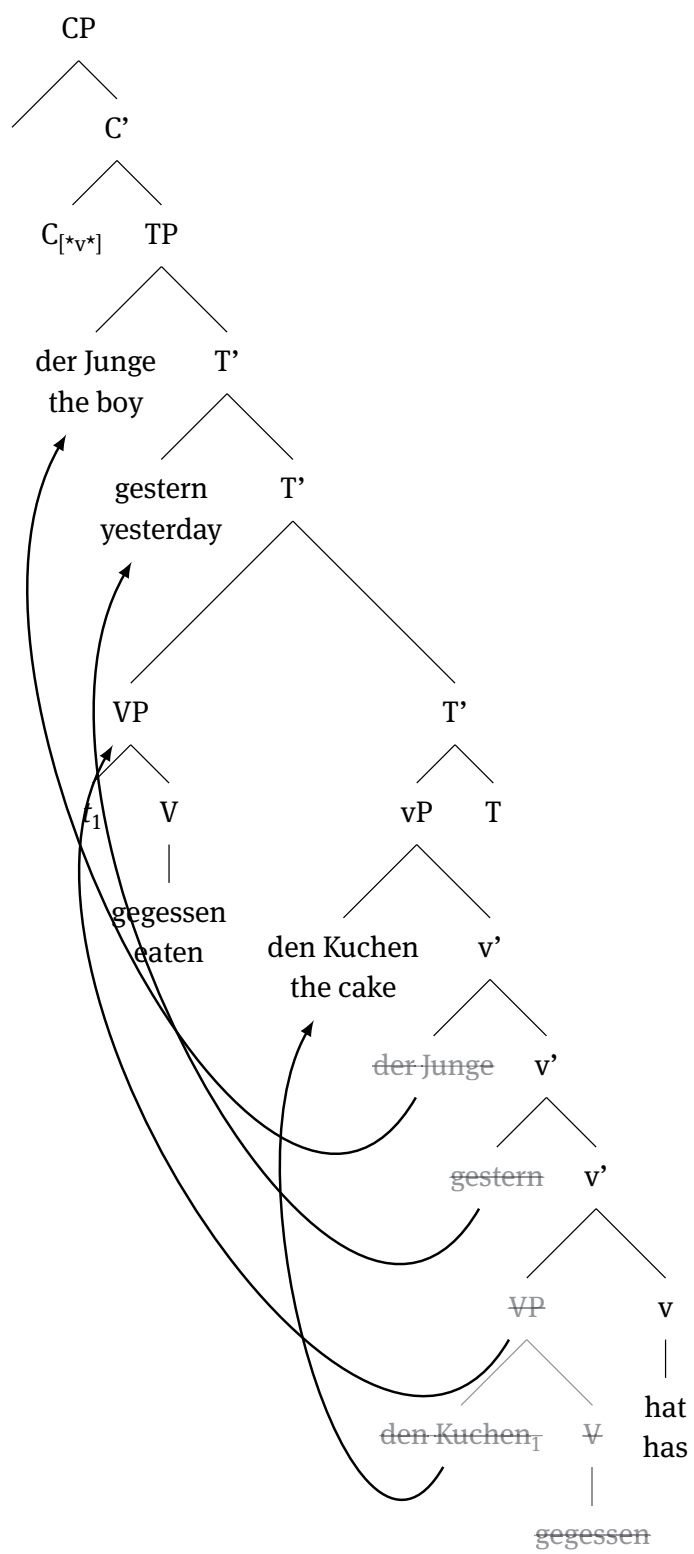

I will not discuss further sentence types but rather focus on the mechanism. Movement is feature driven. Therefore, the movement of $\mathrm{vP}$ to Spec-CP must be induced by a feature. Müller (2004) assumes that the $C$-head bares a strong feature [ $\left.{ }^{\star} \mathrm{V}^{\star}\right]$ 
which attracts vP. In this respect, the remnant movement account has to stipulate the attraction mechanism in the same way as the traditional account does for the head movement. Furthermore, Müller (2004) has to assume additional movement triggers to enable the evacuation of the $\mathrm{vP}$, such as an optional $\left[{ }^{\star} \mathrm{D}^{\star}\right]$ feature on $\mathrm{T}$ (Müller 2004: 189).

\subsubsection{Semantico-pragmatic accounts of V2}

Semantico-pragmatic accounts of V2 received a lot of attention in the last thirty years (e. g. Wechsler 1991, Brandner 2004, Truckenbrodt 2006a,b, Julien 2015, Lohnstein 2020). I will not go into the details of the differences between these formalizations but rather focus on the common core and sketch two problematic issues.

The history of these accounts starts with the observation of Hooper \& Thompson (1973) that root transformation apply only in asserted clauses. Common to the above-mentioned accounts is that they derive the illocutionary force in a combinatorial fashion in which verb movement plays an essential part. Truckenbrodt (2006a), for instance, assumes that the CP bears context indices which must be checked via verb movement. These context indices specify the deontic aspect of the speech act, i. e. what the speaker wants in uttering the sentence. Imperative morphology specifies that the speaker wants the addressee to perform what is denoted by the clause. Declaratives and interrogatives are used in acts to change the epistemic states of the interlocutors: Declaratives are used to assert something, i. e. the addressee should accept the content of the utterance. Interrogatives are used to ask the addressee for information. Whereas in -wH clauses, verb movement is essential for evaluating the epistemic component, the crucial effect in + wH clauses reduces to addressee-specification. This already indicates that the ascribed function of computing the illocutionary potential is non-trivial and verb movement does not serve only one purpose. The two effects are devoted to different properties of the verb: verbal mood for the epistemic component and subjectverb agreement for addressee-specification.

Semantico-pragmatic accounts are very attractive because they provide an explanation for why the verb actually has to move. They have in common that they assume that verb-movement is triggered by the need to type a clause, i. e. to express some kind of illocutionary force. And while there seems to be a strong correlation between verb position and clause types, there remain two major issues that relate to the cross-linguistic, the inter-linguistic, and the intra-linguistic level. The first issue concerns the cross-linguistic generality of the claim that illocutionary force has to be marked explicitly by a syntactic mechanism such as 
verb movement. Proponents of these accounts must explain why (probably) a majority of languages does not show explicit marking for declarative assertions, i. e. how illocutionary force is activated in these cases and why this presumably more economic mechanism is not available in V2-languages. The second issue concerns the correlation between formal properties of sentences (V1, V2, etc.) and their illocutionary force, which is not as uniform as we would expect. On the one hand, we have seen in Section 2.2 that German also exhibits independent utterances without verb movement (see Bayer 2004: 88-89). On the other hand, the mechanism seems to be language-specific because in Kashmiri several types of subordinate clauses (e. g. complement clauses and causal clauses) show obligatory V2movement without being independent illocutions (Bhatt \& Yoon 1991, Bhatt 1995, Koul \& Wali 2015). If, however, the effect of verb movement is not uniform, it begs the question why V2-languages show such a similar behavior in root clauses.

\subsubsection{Summary of the explanatory accounts}

The accounts for V2 that have been discussed in this section can be divided into two groups. The syntactic accounts focus on the mechanisms that derive the correct word order patterns by specifying appropriate features in the respective positions. The semantico-pragmatic accounts, on the hand, try to connect these movement-triggering features with specific aspects of illocutionary properties of the sentences.

\subsection{Chapter summary}

The review of the observations about the V2-phenomenon showed that movement of the finite verb in main clauses can never be suspended. In Section 2.1.3, I discussed two configurations in which specific verb forms cannot move into the V2position. Crucially, however, even in these configurations they cannot remain in their clause-final base position. Movement of phrasal constituents, on the other hand, seems to be much less general. V2-languages exhibit regular V1-structures as well as structures in which more than one element precedes the finite verb. Additionally, phrasal movement seems to be directly related to interpretational properties of the elements involved, such as topicality, contrast, etc. Verb movement, in contrast, does not seem to have such a specific meaning component.

The examination in this chapter also showed that V2-order is only the most frequent pattern in main clauses but V1- and V3-orders also occur regularly in the languages at hand. The review of the theoretical accounts revealed that a more 
precise definition is that the finite verb moves to a certain position. This position is definable in relation to other constituents such as subject and topic, and we might call it the C-position. Constitutional for V2-languages is therefore the relation between the base position of the verb $(\mathrm{V})$ and the high, left-peripheral position (C). This is the core insight of the den Besten (1983) analysis which remains the most accurate and economic analysis until today. I have indicated that a class of accounts try to establish a connection between the movement trigger and the illocutionary potential of matrix clauses. The hypothesis that will be presented in the next chapter complements these observations insofar as it indicates that V2movement is triggered by an abstract feature which is tied to finiteness inflection in German. However, the remainder of this book does not double down on the cause of V2-movement but focuses on the consequences especially for processing V2-clauses. 